REVIEW ARTICLE

\title{
Foliar pathogenic fungi: growing threats to global food security and ecosystem health
}

\section{Udayanga, S.D. Miriyagalla, I.S. Herath, L.A. Castlebury, H.S. Ferdinandez and D.S. Manamgoda}

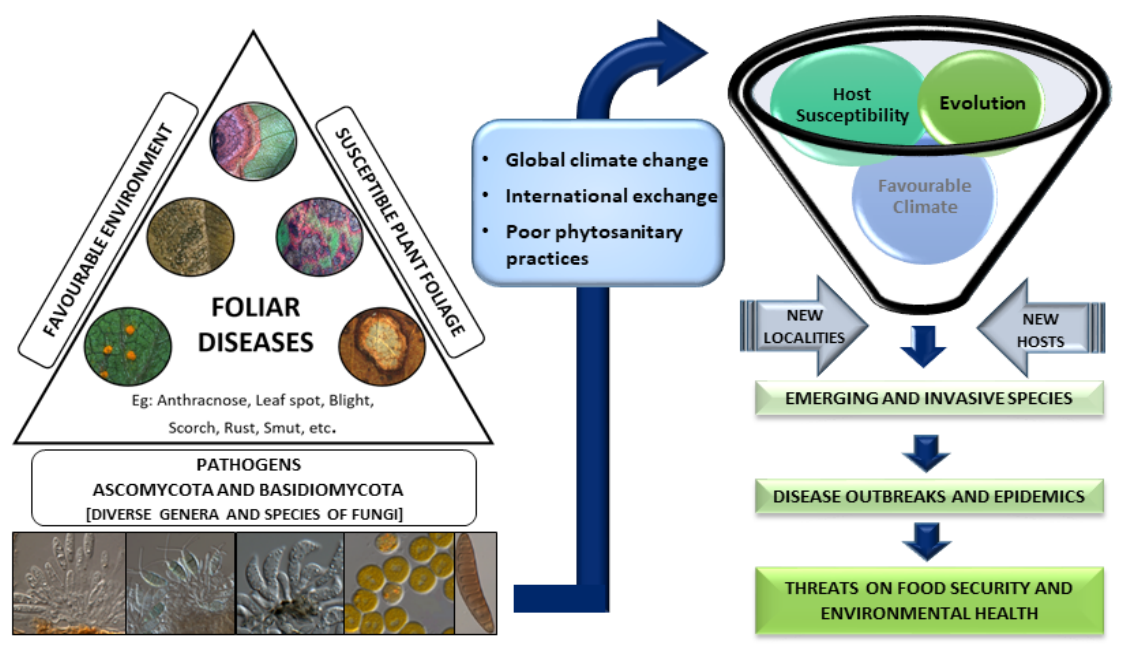

\section{Highlights}

- Foliar pathogens represent a diverse assemblage of species in the fungal kingdom.

- Global climate change, increasing international trade of plant material, and poor phytosanitary practices lead to the spread of destructive diseases.

- Non-indigenous, invasive foliar pathogens cause threats to food security and ecosystem health.

- Therefore, emerging foliar diseases should not be ignored, especially when encountered on the new hosts and localities.

- Understanding evolutionary relationships, diversity, and biology of organisms are vital to avert disease epidemics. 
REVIEW ARTICLE

\title{
Foliar pathogenic fungi: growing threats to global food security and ecosystem health
}

\author{
D. Udayanga ${ }^{1, *}$, S.D. Miriyagalla ${ }^{1}$, I.S. Herath ${ }^{1}$, L.A. Castlebury ${ }^{2}$ H. S. Ferdinandez ${ }^{3}$ and D.S. Manamgoda ${ }^{3}$ \\ ${ }^{1}$ Department of Biosystems Technology, Faculty of Technology, University of Sri Jayewardenepura, Pitipana, \\ Homagama, 10200, Sri Lanka. \\ ${ }^{2}$ Mycology and Nematology Genetic Diversity and Biology Laboratory, United States Department of Agriculture \\ Agricultural Research Service, Beltsville, MD 20705, USA. \\ ${ }^{3}$ Department of Botany, Faculty of Applied Sciences, University of Sri Jayewardenepura, Gangodawila, Nugegoda, \\ 10250, Sri Lanka.
}

Received: 06/09/2020 ; Accepted: 16/10/2020

\begin{abstract}
Globally, foliar pathogenic fungi cause serious losses of annual and perennial crops, ornamentals, landscape plants and forest trees. Plant pathogens that infect foliage are a diverse assemblage of fungi representing both phyla: Ascomycota and Basidiomycota. Although most of the species found on living leaves have been well studied by mycologists and plant pathologists, recent studies have remarkably enhanced the current understanding of species numbers and their evolutionary relationships. The impact of global climate change, the increasing international exchange of plant material and the lack of proper phytosanitary practices have resulted in the potential reemergences of formerly known destructive fungi, infecting new hosts in new geographic locations. Routinely inspecting diseased plants and accurately identifying and naming causative agents are vital for mitigating the impact of invasive and other nonindigenous pathogens on crops and native flora. It is also necessary to characterise foliar pathogenic fungi based on molecular phylogeny, morphology, pathogenicity and the comparative analysis of fungal genomic data. This review provides an overview of prevalent groups of foliar pathogenic fungi, their diversity and economic impact, while emphasising emerging and destructive species that threaten global food security and ecosystem health
\end{abstract}

Keywords: Climate change, Emerging pathogens, Epidemics, Invasive fungi, Leaf diseases.

\section{INTRODUCTION}

Plant pathogenic species comprise a diverse array of taxa in the kingdom of fungi (Hawksworth, 2001; Arnold, 2007; Naranjo-Ortiz and Gabaldón, 2019). Plant diseases have resulted in significant losses of yield in crops, leading to serious economic and social issues (Klinkowski, 1970; McDonald and McDermott, 1993; Alam and Rolfe, 2006; Marin-Felix et al., 2017). The fungi that cause foliar diseases have received special attention because they are frequently encountered in nature and are biologically and ecologically significant (Howard and Valent, 1996; Marin et al., 2003).

Many foliar pathogens are recognised as 'obligate biotrophs', which implies that their growth and reproduction totally depend on the host, while others are opportunistic species or secondary invaders (Chaure et al., 2000). Foliar diseases decrease primary production by reduction of photosynthetic area and function (Barón et al., 2012). In severe foliar fungal infections, plant defoliation and death may occur. Non-indigenous, invasive fungi have had a significant effect on native flora, due to their severity of infection and difficulty to control (Allen and Humble, 2002; Rossman, 2008).

Foliar fungal diseases are traditionally named for the symptoms observed or for the common phytopathological term used to refer to the group of fungi causing the disease. For example, informal categories of common foliage diseases, which are regularly found in the literature, include: anthracnose, leaf spots, leaf blights, tip blight, leaf scorch, leaf blotch, wilting, powdery mildews, rusts, and smuts (Callan and Carris, 2004). These phytopathological terms, however, do not always reflect the nature and evolutionary relationships of the causative agents or the disease (Figure 1). Routine collections of foliar fungi and morphological identification of fungal species have been traditionally practiced by both plant pathologists and mycologists and characterised based on disease incidence and microscopic characteristics, coupled with pathogenicity data. These contributions have resulted in numerous disease reports, morphological descriptions and checklists. However, over the last few decades, the development of fungal molecular systematics has revolutionised the identification, species delimitation and phylogenetic placement of pathogenic species (Nilsson et al., 2014; Crous et al., 2015; Hibbett et al., 2016). Therefore, it is now possible to place pathogenic fungi in a natural classification system via molecular data linked to vouchered specimens and cultures (Shenoy et al. 2007; Damm et al., 2010; Udayanga et al., 2011; 2012; Kõljalg et al., 2013). Accurate species identification based on DNA sequences and phylogenetic reconstructions have now become routine approaches in evolutionary phytopathology, supporting plant pathologists in detection, diagnostics, diversity estimation, disease surveillance and management. Additionally, historical disease collections made by numerous mycologists and plant pathologists 
are available in several international herbaria around the world. These collections are excellent sources for the sampling of taxa collected in the past from different geographic regions of the world. The pieces of evidence gathered based on these specimens provide a significant contribution to epidemiological efforts of predicting disease origins, modeling of dispersal patterns, and foreshadowing potential invasions.

Foliar diseases on crops and ornamentals have caused invasions, severe outbreaks and epidemics in human history. One such outbreak of coffee leaf rust, caused by the fungus Hemileia vastatrix, hit the celebrated coffeeproduction areas of Sri Lanka (then known as Ceylon) circa 1869. The same fungus has been the cause of recent coffee rust disease outbreaks in Colombia (2008 to 2011), Central America and Mexico (2012 to 2013) and Peru and Ecuador (2013), leading to an ongoing crisis in global trade (Avelino et al., 2015; World Coffee Research, 2018; Amico et al., 2020). Due to its significant impact on trade, coffee rust is considered one of the most economically important coffee diseases worldwide (Villarreyna et al., 2020). The dematiaceous hyphomycete, Bipolaris oryzae, causes devastating brown spot diseases in rice. This was one of the factors leading to India's Bengal famine of 1943 (Scheffer, 1997). Although it has not caused severe outbreaks in recent times, the same fungus is still being encountered in major rice growing regions worldwide (Manamgoda et al., 2014; Sobanbabu et al., 2018). The rice blast fungus, Pyricularia oryzae (syn. Magnaporthe oryzae), is considered the most destructive leaf pathogen in rice, causing recurrent outbreaks (Couch and Kohn, 2002). This disease is difficult to control and destroys up to $30 \%$ of the world's rice crop each year, resulting in potential economic and humanitarian crises, particularly in Asia (Savary et al., 2000; Saleh et al., 2014; Khan et al., 2016; Nalley, 2016). Pyricularia oryzae is widely used to study the molecular basis of diseases and hostpathogen interactions (Dean et al., 2012). Boxwood blight is another invasive disease, which originated in the United Kingdom in 1994 and is currently distributed throughout Asia, Europe, North America, and New Zealand (LeBlanc et al., 2018). As the name suggests, boxwood blight is a disease affecting boxwood (Buxus spp.) and causes rapid defoliation and the latent dieback of foliage (MalapiWight et al., 2014; Daughtrey, 2019). Recent outbreaks of boxwood blight disease, caused by the fungus Calonectria pseudonaviculata, threaten the health and productivity of boxwood in both landscape plantings and nurseries, posing a major threat to the ornamental plant industry (LeBlanc et al., 2018). Plants infected by C. pseudonaviculata are eventually weakened, and the resulting plant stress and consequent colonisation by secondary invaders often results in plant death.

Though surveillance and management methods can be effectively applied to prevent severe impacts, many of the fungi causing outbreaks have no cure. The past few decades have witnessed an increasing number of severe fungal infectious diseases in natural populations of humans, animals and plants (Vinatzer et al., 2019). As with the recent global challenge of the novel coronavirus disease (COVID-19) in humans, scientists predict that a potential crop pandemic will occur sooner rather than later. It is highly likely that such an outbreak will be caused by a plant pathogenic fungus (Owings, 2020; Broom, 2020; Horvath, 2020). Potential outbreaks of phytopathogenic fungi could impact food supply systems by crop production in the affected areas. However, with the global population projected to number more than nine billion by 2050, the food supply will need to be protected to satisfy increasing demand.

Foliar fungal diseases have received much attention in recent history because they cause rapid losses in crop production. Some plant pathogenic fungi have intricate or poorly understood lifecycles, and few discriminatory morphological characteristics (Wikee et al., 2011; Aime et al., 2018). Therefore, understanding the biology, ecology, diversity and evolution of foliar pathogenic fungi is key to predicting threats and implementing mitigation strategies. This review outlines the diversity and impact of foliar pathogenic fungi based on key examples of prevalent fungal groups associated with economically important plants, with emphasis on emerging and potentially invasive species. Furthermore, we highlight the potential threats by foliar pathogenic fungi in the future on global food security and ecosystem health, based on their records of known historical impact on food crops or other economically important plants.

\section{Diversity of foliar pathogens in the fungal kingdom}

Foliar pathogenic species are a diverse assemblage of fungi belonging to both Ascomycota and Basidiomycota. These include many well-known pathogenic groups. The fungal classes Dothideomycetes, Sordariomycetes and Leotiomycetes, in Ascomycota are composed of ecologically diverse species, including many foliar pathogens that affect high value crops, ornamentals and forest trees (Table 1). Similarly, fungi belonging in Basidiomycota are wellknown causative agents of a large number of severe fungal plant diseases. For instance, rust fungi, belonging in the Basidiomycota, class Pucciniomycetes, are widely distributed parasites found in various geographic locations worldwide (Arthur, 1934; Savile, 1971; Smith et al., 2004; Padamsee et al., 2012; Aime et al., 2014). Smut fungi make up a second well-known group, consisting of a few severe foliar pathogens that parasitize cereals and fibre crops. Another well-known basidiomycetous foliar pathogenic genus, Exobasidium, which includes the causative agent of blister blight in tea (E. vexans) belongs to the class Exobasidiomycetes (Sinniah et al., 2016; Weerasooriya et al., 2018). Exobasidium vexans is a relatively poorly studied obligate biotrophic pathogen, but it has serious ramifications for the quality of tea production (Chaliha et al., 2019).

Apart from well-known foliar fungi, a large number of novel leaf diseases and host associations occurring in crops, ornamental plants and forest trees are being reported in recent phytopathological and mycological literature (Chen et al., 2018; Rodriguez-Salamanca, 2018; Tsai et al., 2018; Salgado-Salazar et al., 2019; Liang et al., 2019). These previously undescribed fungi are commonly encountered 

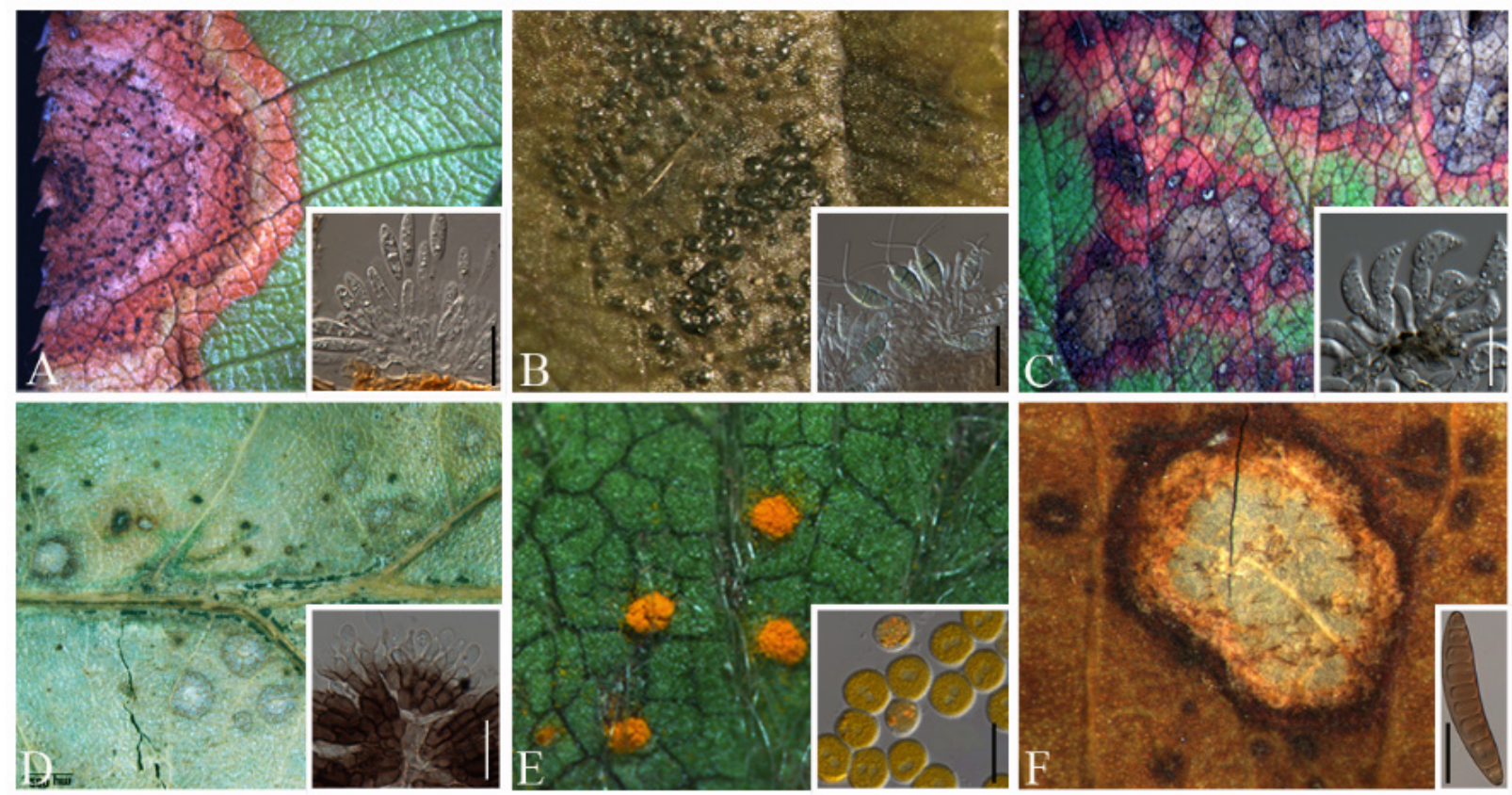

Figure 1 : Microscopic images of some foliar diseases and their causative agents.

A) Leaf blight on Prunus serrulata (Japanese cherry) caused by Botryosphaeria dothidea B) Leaf blight of Fragaria $\times$ annassa (cultivated strawberry) caused by Neopestalotiopsis sp. C) Leaf scorch of Fragaria $\times$ annassa caused by Diplocarpon fragariae D) Oak blight of Quercus macrocarpa (Bur Oak) caused by Tubakia iowensis E) Orange rust on Duchesnea indica (mock strawberry) caused by Phragmidium tormentillae F) Bird's eye spot of Hevea brasiliensis (Pará rubber) caused by Bipolaris heveae. Scale bars: A-F: $10 \mu \mathrm{m}$. Images were captured using a Discovery V20 stereomicroscope and AxioCam HrC digital camera (Carl Zeiss Microscopy, Thornwood, New York, USA) imaging system.

in relatively unexplored habitats, and numerous cryptic species are also being revealed in molecular mycological studies. According to Hawksworth and Rossman (1997), many fungal species have been collected, but remain lost or hidden as named species or ignored because they lack modern characterisations. Although a large number of genera and species of plant pathogenic fungi have been documented in the extant body of literature, most names are either not in use or the fungi are otherwise poorly known (Marin-Felix et al., 2017). Therefore, it is not surprising that the foliar pathogenic continuum of fungi has yet to be fully explored, particularly among many poorly studied groups.

\section{Host, pathogen and environment for the emergence of foliar diseases}

Although fungi are commonly associated with leaf diseases, most fungal diseases minimally affect the plant's overall leaf area, causing minor biotic stress in terms of overall growth and development. Annual crops are infected with leaf pathogens mostly at the latent stage of growth or near harvest; thus, they may minorly impact production in most cases. However, environmental changes can directly influence the development and survival rates of foliar pathogens, modify host susceptibility and subsequently alter the effects of the diseases on host plants (Fisher, 2012; Elad and Pertot, 2014; Velásquez et al., 2018). In hot and humid conditions, when infection pressures for fungal pathogens are high, leaf pathogens can cause severe defoliation and plant death. Therefore, climate factors, pathogen virulence and the dynamics of foliar disease add an extra level of complexity to plant protection. In addition, pathogen growth rates and the production and germination of propagules strongly depend on temperature, relative humidity and, in the case of foliar pathogens, often leaf wetness (Colhoun, 1973; Huber and Gillespie, 1992).

Plant foliage is the often the first line of contact for invasive and non-indigenous fungal species. Most foliar pathogens, when successfully colonised on leaves, have the advantage of being able to be dispersed by the wind, making them widely distributed across geographical borders. Some foliar fungal species asymptomatically hitchhike within the plant tissues as endophytic fungi and can become latent pathogens on the same or different hosts when the environmental conditions are favourable (Petrini et al., 1991; Slippers and Wingfield, 2007; Gomes et al., 2013).

Crops heavily sprayed with fungicides might never show infections from some common foliar pathogens (Haq et al., 2020). However, leaf diseases are often taken seriously only if they result in a sudden outbreak or cause moderate to complete defoliation a few years in a row. Leaf loss over several consecutive growing seasons in plants infected with destructive foliar fungi can result in increased levels of inoculum, reduced growth, and increased susceptibility to pests and other diseases, leading to severe economic losses or environmental threats. 
Table 1: Examples of destructive foliar pathogenic fungal species causing diseases on crops and ornamentals, their current classification, prevalent host(s), disease and supporting literature.

\begin{tabular}{|c|c|c|c|c|}
\hline $\begin{array}{l}\text { Foliar pathogenic } \\
\text { species (current } \\
\text { name) }\end{array}$ & $\begin{array}{l}\text { Current classification } \\
\text { (Phylum, Class \& } \\
\text { Order) }\end{array}$ & $\begin{array}{l}\text { Prevalent } \\
\text { Host(s)* }\end{array}$ & Foliar disease & Supporting Literature \\
\hline Austropuccinia psidii & $\begin{array}{l}\text { Phylum: Basidiomycota } \\
\text { Class: Pucciniomycetes } \\
\text { Order: Pucciniales }\end{array}$ & $\begin{array}{l}\text { Myrtaceae } \\
\text { hosts }\end{array}$ & Myrtle rust & du Plessis (2019) \\
\hline Bipolaris oryzae & $\begin{array}{l}\text { Phylum: Ascomycota } \\
\text { Class: Dothideomycetes } \\
\text { Order: Pleosporales }\end{array}$ & $\begin{array}{l}\text { Oryza sativa } \\
\text { (rice) }\end{array}$ & Brown spot of rice & $\begin{array}{l}\text { Manamgoda et al., (2014); } \\
\text { Sobanbabu et al., (2018) }\end{array}$ \\
\hline Bipolaris maydis & $\begin{array}{l}\text { Phylum: Ascomycota } \\
\text { Class: Dothideomycetes } \\
\text { Order: Pleosporales }\end{array}$ & $\begin{array}{l}\text { Zea mays } \\
\text { (maize) }\end{array}$ & $\begin{array}{l}\text { Southern leaf } \\
\text { blight of corn }\end{array}$ & $\begin{array}{l}\text { Manamgoda et al., (2014); Macedo } \\
\text { et al., (2016) }\end{array}$ \\
\hline Bipolaris sorokiniana & $\begin{array}{l}\text { Phylum: Ascomycota } \\
\text { Class: Dothideomycetes } \\
\text { Order: Pleosporales }\end{array}$ & $\begin{array}{l}\text { Triticum } \\
\text { aestivum } \\
\text { (wheat) }\end{array}$ & Leaf spot & $\begin{array}{l}\text { Wang and Wei (2016); Li et al., } \\
\text { (2019) }\end{array}$ \\
\hline Cercospora sojina & $\begin{array}{l}\text { Phylum: Ascomycota } \\
\text { Class: Dothideomycetes } \\
\text { Order: Capnodiales }\end{array}$ & $\begin{array}{l}\text { Glycine } \max \\
\text { (soybean) }\end{array}$ & Frog eye leaf spot & $\begin{array}{l}\text { Zhang and Bradley (2014); } \\
\text { Shreshta et al., (2017) }\end{array}$ \\
\hline $\begin{array}{l}\text { Calonectria } \\
\text { pseudonaviculata }\end{array}$ & $\begin{array}{l}\text { Phylum: Ascomycota } \\
\text { Class: Sordariomycetes } \\
\text { Order: Hypocreales }\end{array}$ & Buxus sp. & Boxwood blight & Gauthier and Dockery (2018) \\
\hline Colletotrichum spp. & $\begin{array}{l}\text { Phylum: Ascomycota } \\
\text { Class: Sordariomycetes } \\
\text { Oder: Glomerellales }\end{array}$ & $\begin{array}{l}\text { Hevea } \\
\text { brasiliensis } \\
\text { (Pará rubber) }\end{array}$ & $\begin{array}{l}\text { Colletotrichum } \\
\text { Leaf Disease / } \\
\text { CLD }\end{array}$ & $\begin{array}{l}\text { Hunupolagama et al., (2017); Cao } \\
\text { et al., (2019) }\end{array}$ \\
\hline Colletotrichum spp. & $\begin{array}{l}\text { Phylum: Ascomycota } \\
\text { Class: Sordariomycetes } \\
\text { Order: Glomerellales }\end{array}$ & $\begin{array}{l}\text { multiple genera } \\
\text { of plants }\end{array}$ & Anthracnose & $\begin{array}{l}\text { Cao et al (2019); Nascimento et al } \\
\text { (2019) }\end{array}$ \\
\hline Diaporthe ampelina & $\begin{array}{l}\text { Phylum: Ascomycota } \\
\text { Class: Sordariomycetes } \\
\text { Order: Diaporthales }\end{array}$ & $\begin{array}{l}\text { Vitis spp., } \\
\text { Ampelopsidis } \\
\text { spp. }\end{array}$ & Cane and leaf spot & Guarnaccia et al., (2018) \\
\hline Diplocarpon fragariae & $\begin{array}{l}\text { Phylum: Ascomycota } \\
\text { Class: Leotiomycetes } \\
\text { Order: Helotiales }\end{array}$ & $\begin{array}{l}\text { Fragaria } \mathrm{sp} . \\
\text { (strawberry) }\end{array}$ & Leaf scorch & $\begin{array}{l}\text { Sivanesana and Gibson (1976); } \\
\text { Johnston } \text { et al., (2014) }\end{array}$ \\
\hline Discula destructiva & $\begin{array}{l}\text { Phylum: Ascomycota } \\
\text { Class: Sordariomycetes } \\
\text { Order: Diaporthales }\end{array}$ & Cornus spp. & $\begin{array}{l}\text { Dogwood } \\
\text { anthracnose }\end{array}$ & $\begin{array}{l}\text { Redlin (1991); Trigiano et al., } \\
\text { (2016) }\end{array}$ \\
\hline Entyloma helianthi & $\begin{array}{l}\text { Phylum: Basidiomycota } \\
\text { Class: Exobasidiomycetes } \\
\text { Order: Entylomatales }\end{array}$ & $\begin{array}{l}\text { Helianthus } \\
\text { annuus } \\
\text { (sunflower) }\end{array}$ & $\begin{array}{l}\text { Sunflower leaf } \\
\text { smut }\end{array}$ & Rooney-Latham et al., (2017) \\
\hline Entyloma oryzae & $\begin{array}{l}\text { Phylum: Basidiomycota } \\
\text { Class: Exobasidiomycetes } \\
\text { Order: Entylomatales }\end{array}$ & $\begin{array}{l}\text { Oryza sativa } \\
\text { (rice) }\end{array}$ & Rice leaf smut & $\begin{array}{l}\text { Mulder and Holliday (1971); Vanky } \\
\text { (2012) }\end{array}$ \\
\hline Exobasidium vexans & $\begin{array}{l}\text { Phylum: Basidiomycota } \\
\text { Class: Exobasidiomycetes } \\
\text { Order: Exobasidiales }\end{array}$ & $\begin{array}{l}\text { Camellia } \\
\text { sinensis (tea) }\end{array}$ & Blister blight & Mabbett (2016) \\
\hline Exserohilum turcicum & $\begin{array}{l}\text { Phylum: Ascomycota } \\
\text { Class: Dothideomycetes } \\
\text { Order: Pleosporales }\end{array}$ & $\begin{array}{l}\text { Zea mays } \\
\text { (maize) }\end{array}$ & $\begin{array}{l}\text { Northern leaf } \\
\text { blight of corn }\end{array}$ & $\begin{array}{l}\text { Hernandez-Restrepo et al., (2018); } \\
\text { Nieuwoudt et al., (2018) }\end{array}$ \\
\hline Hemileia vastatrix & $\begin{array}{l}\text { Phylum: Basidiomycota } \\
\text { Class: Pucciniomycetes } \\
\text { Order: Pucciniales }\end{array}$ & Coffea spp. & Coffee rust & $\begin{array}{l}\text { Talhinhas et al., (2017); Santana et } \\
\text { al., (2018) }\end{array}$ \\
\hline Melampsora medusae & $\begin{array}{l}\text { Phylum: Basidiomycota } \\
\text { Class: Pucciniomycetes } \\
\text { Order: Pucciniales }\end{array}$ & Populus spp. & Poplar leaf rust & $\begin{array}{l}\text { Feau et al., (2009); Newcombe and } \\
\text { Chastagner (1993) }\end{array}$ \\
\hline
\end{tabular}




\begin{tabular}{|c|c|c|c|c|}
\hline $\begin{array}{l}\text { Phakopsora } \\
\text { pachyrhizi }\end{array}$ & $\begin{array}{l}\text { Phylum: Basidiomycota } \\
\text { Class: Pucciniomycetes } \\
\text { Order: Pucciniales }\end{array}$ & $\begin{array}{l}\text { Glycine max } \\
\text { (soybean) }\end{array}$ & Asian soybean rust & Rincão et al., (2018) \\
\hline Podosphaera xanthii & $\begin{array}{l}\text { Phylum: Ascomycota } \\
\text { Class: Leotiomycetes } \\
\text { Order: Erysiphales }\end{array}$ & $\begin{array}{l}\text { multiple genera } \\
\text { of plants. }\end{array}$ & Powdery mildew & $\begin{array}{l}\text { Chen et al., (2017); Cho et al., } \\
\text { (2017) }\end{array}$ \\
\hline $\begin{array}{l}\text { Pseudocercospora } \\
\text { fijiensis }\end{array}$ & $\begin{array}{l}\text { Phylum: Ascomycota } \\
\text { Class: Dothideomycetes } \\
\text { Order: Capnodiales }\end{array}$ & $\begin{array}{l}\text { Musa spp. } \\
\text { (banana) }\end{array}$ & $\begin{array}{l}\text { Black Sigatoka } \\
\text { disease (black leaf } \\
\text { streak) }\end{array}$ & $\begin{array}{l}\text { Manzo-Sanchez et al., (2019); } \\
\text { Fullerton and Casonato (2019) }\end{array}$ \\
\hline Puccinia triticina & $\begin{array}{l}\text { Phylum: Basidiomycota } \\
\text { Class: Pucciniomycetes } \\
\text { Order: Pucciniales }\end{array}$ & Triticum spp. & Wheat leaf rust & $\begin{array}{l}\text { Terefe et al., (2014) } \\
\text { Kolmer (2015) }\end{array}$ \\
\hline Pyricularia oryzae & $\begin{array}{l}\text { Phylum: Ascomycota } \\
\text { Class: Sordariomycetes } \\
\text { Order: Magnaporthales }\end{array}$ & $\begin{array}{l}\text { Oryza sativa } \\
\text { (rice) }\end{array}$ & Rice blast disease & $\begin{array}{l}\text { Klaubauf et al., (2014); Milazzo et } \\
\text { al., (2019) }\end{array}$ \\
\hline Spilocaea oleagina & $\begin{array}{l}\text { Phylum: Ascomycota } \\
\text { Class: Dothideomycetes } \\
\text { Order: Pleosporales }\end{array}$ & $\begin{array}{l}\text { Olea spp. } \\
\text { (Olive) }\end{array}$ & Peacock leaf spot & González-Lamothe et al., (2002) \\
\hline Teratosphaeria spp. & $\begin{array}{l}\text { Phylum: Ascomycota } \\
\text { Class: Dothideomycetes } \\
\text { Order: Capnodiales }\end{array}$ & Eucalyptus spp. & Leaf blight & Crous et al., (2009); (2019) \\
\hline Urocystis cumminsii & $\begin{array}{l}\text { Phylum: Basidiomycota } \\
\text { Class: Ustilaginomycetes } \\
\text { Order: Urocystidales }\end{array}$ & $\begin{array}{l}\text { Dichelostemma } \\
\text { capitatum }\end{array}$ & Leaf smut & Savchenko et al., (2020) \\
\hline Urocystis tritici & $\begin{array}{l}\text { Phylum: Basidiomycota } \\
\text { Class: Ustilaginomycetes } \\
\text { Order: Urocystidales }\end{array}$ & $\begin{array}{l}\text { Triticum spp. } \\
\text { (wheat) }\end{array}$ & Flag smut & Savchenko et al., (2016) \\
\hline Ustilago cynodontis & $\begin{array}{l}\text { Phylum: Basidiomycota } \\
\text { Class: Ustilaginomycetes } \\
\text { Order: Ustilaginales }\end{array}$ & $\begin{array}{l}\text { Cynodon } \\
\text { dactylon }\end{array}$ & Leaf stripe smut & Kruse et al., (2018) \\
\hline Ustilago serpens & $\begin{array}{l}\text { Phylum: Basidiomycota } \\
\text { Class: Ustilaginomycetes } \\
\text { Order: Ustilaginales }\end{array}$ & Elymus repens & Leaf stripe smut & Kruse et al., (2018) \\
\hline Zymoseptoria tritici & $\begin{array}{l}\text { Phylum: Ascomycota } \\
\text { Class: Dothideomycetes } \\
\text { Order: Capnodiales }\end{array}$ & $\begin{array}{l}\text { Triticum } \\
\text { aestivum } \\
\text { (wheat) }\end{array}$ & $\begin{array}{l}\text { Leaf spot or } \\
\text { speckled leaf } \\
\text { blotch }\end{array}$ & $\begin{array}{l}\text { Allioui et al., (2016); Harrat et al., } \\
\text { (2017) }\end{array}$ \\
\hline
\end{tabular}

*Other hosts can be retrieved at Fungal Databases of USDA-ARS: https://nt.ars-grin.gov/fungaldatabases/ (Farr and Rossman, 2020)

\section{Colletotrichum, the cause of foliar anthracnose}

Colletotrichum is a genus of plant pathogenic fungi (phylum: Ascomycota; class: Sordariomycetes) with worldwide distribution (Hyde et al., 2009; Cannon et al., 2012). Anthracnose caused by Colletotrichum species is primarily defined as sunken necrotic spots or blights on leaves, stems, flowers or fruits (Udayanga et al., 2013; Shivas et al., 2016; De Silva et al., 2017; Sangpueak et al., 2018). Foliar anthracnose is commonly found in tropical and subtropical environments, affecting wide ranges of crops, including cereals, grasses, vegetables, ornamentals and forest trees (Alahakoon et al., 1994; Crouch et al., 2009; Lobato et al., 2010; Nair, 2010; Rojas et al., 2010; Damm et al., 2012a, 2012b). Therefore, the foliar Colletotrichum species are considered to be a major cause of pre- and post-harvest loss of a wide range of high-value crops, and these species are also commonly encountered in plant biosecurity interceptions (Udayanga et al., 2013; Shivas et al., 2016; De Silva et al., 2017).
Collectotrichum species are frequently encountered in routine collections of leaf necrotic symptoms. These species usually co-occur with other ascomycetes, either as primary pathogens or as secondary invaders. Amongst prevailing foliar diseases, anthracnose caused by Colletotrichum species is one of the most severe diseases among cultivated rubber trees (Hevea brasiliensis) (Liu et al., 2018). Colletotrichum Leaf Disease (CLD) is a major cause of declining rubber yields in South East Asia. In Sri Lanka, CLD reached an epidemic magnitude in February and March 1996 due to unusually wet weather (Jayasinghe et al., 1997). In many parts of the world, Colletotrichum gloeosporioides is the causative agent of CLD in rubber. Apart from the species in the C. gloeosporioides species complex, C. acutatum is also a major causative agent of CLD, particularly in Sri Lanka (Jayasinghe et al., 1997). The most common CLD symptom in rubber is small to large circular lesions on mature and immature leaves. CLD development may also significantly reduce rubber yield by secondary leaf fall. In severe epidemics, CLD also affects 
young twigs with premature leaves, causing the tips to blacken and the typical brown to black anthracnose lesions to form on the green stems (Hunupolagama et al., 2017).

Accurately identifying the species causing CLD is critical for understanding the epidemiology and developing effective control measures. However, the genus Colletotrichum contains many species with overlapping morphological characteristics, which may vary due to environmental conditions and geography, thus making species delimitation difficult. Therefore, an approach involving both morphological characteristics and multiloci phylogenetic analysis is recommended for accurately identifying these Colletotrichum species (Cai et al., 2009). According to Marin-Felix et al., (2017), there are approximately 11 distinct Colletotrichum species complexes: gloeosporioides, boninense, truncatum, acutatum, dematium, gigasporum, orbiculare, graminicola, spaethianum, destructivum and caudatum. Each complex contains numerous phylogenetically closely related species, some of which are rich in species numbers. For example, the gloeosporioides clade alone consists of at least 30 different species, associated with numerous host plants causing minor to severe diseases. This enormous diversity and the frequent occurrence of foliar Colletotrichum pathogenic species in nature highlights the need for repeated collection and identification, particularly from unexplored ecosystems, to understand patterns of pathogen distribution and disease incidence. The rapidly growing species numbers, new disease reports and novel host associations of Colletotrichum species in the last two decades illustrate the unprecedented impact of these fungi in agriculture and ornamental trade. Thus, the timely responses to initial outbreaks are essential to prevent a possible impact on high-value crops and native flora.

\section{Diaporthalean fungi causing foliar diseases}

Species of Diaporthales (Ascomycota) have been extensively studied and the order is one of the largest and most well-defined orders in the Sordariomycetes class of Ascomycota (Castlebury et al., 2002; Zhang et al., 2006; Rossman et al., 2007). The order Diaporthales contains a large number of notable fungi causing serious diseases in a wide range of plant hosts, including landscape trees and field crops, across both tropical and temperate natural ecosystems (Zhang and Blackwell, 2001; Adams et al., 2006; Gryzenhout et al., 2006; Udayanga et al., 2014, 2015). An early twentieth century outbreak of the chestnut blight pathogen, Cryphonectria parasitica (Cryphonectriaceae), which belongs to the Diaporthales, caused the defoliation and death of chestnut trees in North America (Anagnostakis 1987; Brewer 1995). Thus, due to their wide occurrence and enormous diversity, the diaporthalean fungi cause devastating diseases in economically important host plants, resulting in sudden outbreaks, local losses and quarantine issues affecting international trade.

Though diaporthalean species are primarily known to cause various stem blights, cankers, root rots and fruit disease, many are also known to cause severe foliar diseases in economically important crops and forest trees. For instance, dogwood anthracnose (Discula destructiva), strawberry leaf blotch (Gnomoniopsis fructicola), and Bur Oak blight (Tubakia iowensis) have caused notable disease incidents. Of these, D. destructiva has significantly impacted wild and ornamental Cornus species in the United States, proving itself to be a potentially devastating fungal disease, in both landscapes and forests throughout the eastern and northwestern United States since the late 1970's. Many genera in the Diaporthales are species-rich and widely encountered as asexual morphs on the leaves and stems of living plants. Diaporthalean fungi are also commonly encountered during quarantine inspections, leading to various issues affecting international trade of plant material (Kačergius et al., 2010; Duan et al., 2016). The wide occurrence and the unexpected diversity of pathogenic species in the Diaporthales have made it possible to cause devastating diseases on economically important host plants, resulting in sudden outbreaks and yield losses.

\section{Foliar pathogenic graminicolous hyphomycetes}

Hyphomycetes are a type of mitosporic fungi, which lack closed fruiting bodies and directly produce conidia via conidiophores during their asexual lifecycles (Ellis, 1971). Graminicolous hyphomycetes are associated with grasses and related crops in the Poaceae plant family (Sivanesan, 1987). Most graminicolous hyphomycetes are helminthosporoid species, which are now divided into six genera - Bipolaris, Curvularia, Drechslera, Exserohilum, Johnalcornia and Porocercospora - belonging to the Pleosporales (Dothideomycetes, Ascomycota) (Sivanesan, 1987; Manamgoda et al., 2012; Amaradasa et al., 2014; Tan et al., 2014; Hernandez-Restrepo et al., 2018). In addition to helminthosporoid graminicolous hyphomycetes, several other fungal genera, encountered as graminicolous hyphomycetes (e.g., alternarioid and cercosporoid fungal species) also have detrimental effects on plants.

Graminicolous hyphomycetes associated with cereal crops and their wild relatives have been reported as destructive phytopathogens, leading to significant yield losses and starvation worldwide. Severe crop losses have been reported in the United Kingdom and the United States, due to Southern corn leaf blight, caused by Bipolaris maydis (Manamgoda et al., 2011), and Northern corn leaf blight, caused by Exserohilum turcicum (Smith et al., 1988). Bipolaris sorokiniana is another common leaf spot pathogen in wheat and barley (Duveiller and Gilchrist, 1994). Though graminicolous hyphomycetes are primarily identified via morphology, successful specieslevel delimitation is always followed by comprehensive phylogenetic analyses incorporating molecular data (Manamgoda et al., 2014, 2015; Tan et al., 2014, 2016, 2018; Marin-Felix et al., 2017, 2020). For instance, species discrimination of the genus Curvularia, solely based on morphological characteristics, is difficult as they share similar characteristics therefore, multi-locus, combined analyses are required in phylogenetic reconstruction (Manamgoda et al., 2015; Tan et al., 2018; Marin-Felix et al., 2017, 2020). However, the diversity, wide distribution and impact of graminicolous hyphomycetes on food and fibre security emphasise the need for the study of these 
fungi, as they can emerge as outbreaks anywhere in the world.

\section{Fungi causing powdery mildew}

Powdery mildew is a common, serious, economically significant disease, which affects various crops (e.g., cereal plants, vegetables, fruit trees and ornamental plants) and has been reported to have an exclusively angiosperm host range (Mori et al., 2000). However, characterised by the formation of a white, powdery film on leaf surfaces, stems or fruits (Mori et al., 2000), powdery mildew is, to a greater degree, considered a foliar pathogen, given the extent of the foliar damage it causes, compared with damage to other plant organs. Powdery mildew is caused by obligate biotrophic pathogenic fungi belonging to the Erysiphaceae family, the sole family in the Erysiphales (class: Leotiomycetes, phylum: Ascomycota) (Ito and Takamatsu, 2009). By reducing leaf surface area for photosynthesis, and thus reducing crop quality and yield, Erysiphales pathogens turn themselves into a major economic concern.

The Erysiphaceae contains 16 genera, including approximately 873 species (Takamatsu et al., 2015). In accordance with molecular-level investigations, all 16 genera are divided into five main tribes: Blumerieae, Golovinomyceteae, Cystotheceae, Erysipheae and Phyllactinieae (Braun, 2010; Takamatsu et al., 2015). The Erysiphales order is reported to house both tree-parasitic and herb-parasitic species. The early divergent species are mostly tree-parasitic, indicating the occurrence of host shifts from trees to herbs over the course of evolution (Takamatsu, 2004). Early speculations concerning the phylogeny and host relationships of Erysiphales were based on critical morphological features (e.g., number of asci, number of ascospores, morphology of appendages, nature of conidiogenesis and mycelium features), whereas more recent taxonomic studies using molecular characteristics have given better insights into the phylogenetic aspects of the order and have helped restructure the taxonomic groups vastly (Takamatsu, 2013). Most of the tribes are well defined by molecular analyses, except Erysipheae, which contains the sole genus Erysiphe - the largest of all genera in the family, accounting for more than half of its species (Takamatsu et al., 2015).

Most economic implications are caused by the herbparasitic, rather than the tree-parasitic, species. Most monocot hosts of powdery mildews (such as wheat, barley, rye, oats, etc.) belonging to the family Poaceae, are valued food crops. These are often associated with a single pathogenic genus, Blumeria, within the Blumerieae tribe (Inuma et al., 2007). The genus Golovinomyces housed within the Golovinomyceteae tribe, comprises the causative agents of powdery mildew in common ornamental plants, such as Asteraceae (daisies), Boraginaceae (borages) and Lamiaceae (mints) (Takamatsu et al., 2013). The most commonly reported cases of Cucurbit Powdery Mildew (CPM) disease affect economically important crops in the Cucurbitaceae family (including cantaloupes, melons, squash and pumpkins). Causative agents of CPM include Podosphaera xanthii of the Cystotheceae tribe and Golovinomyces orontii (syn. Erysiphe cichoracearum); these are considered the major threats to the worldwide cultivation of cucurbits (Pirondi et al., 2015; Rebelo et al., 2017). The three genera - Leveillula, Phyllactinia, and Pleochaeta - in the Phyllactinieae tribe generally infect hosts in the Ulmaceae (elm) and Fabaceae (pea) families. Increasingly incorporating molecular data and new morphological characteristics into taxonomic studies has helped researchers describe new species, as well as asexual morphs of known sexual morphs (Braun, 2010). Several sources record epidemics that resulted from powdery mildews being introduced into regions in which it had not been previously reported. Some historical examples include the introduction of Erysiphe necator, the grape powdery mildew pathogen, into Europe from North America during the nineteenth century and the introduction of Sphaerotheca mors-uvae, or the American gooseberry mildew, into Europe and Asia from North America (Kiss, 2005). Erysiphe flexuosa, which infects horse chestnuts, and E. elevata, which infects Indian beans, are some recent examples of the alien introduction of powdery mildew pathogens into the European region (Ale-Agha et al., 2000). The obligate biotrophic nature of powdery mildews enables them to grow and reproduce exclusively on specific host plants. Additionally, the prodigious production of spores and quick dispersal patterns allow these fungi to infect a wide area of agricultural fields, leading to rapid losses of high-value crops and hindering ornamental trade of plant material.

\section{Rust fungi}

Placed in the order Pucciniales (phylum: Basidiomycota, class: Pucciniomycetes), 'rust fungi' are a species-rich group of parasitic, foliar fungal pathogens, which are capable of inducing extensive economic and ecological damage (Aime et al., 2018). With more than 7,800 species recorded, these obligate biotrophic pathogens belong to approximately 115 to 163 genera (Aime et al., 2006; Figueroa et al., 2020), but the family classifications remain doubtful and require further clarification. Rust fungi have complex life cycles, sometimes involving unrelated but specific plant hosts and (at most) five different spore types. These pathogens can reduce crop yields by depositing rusty-brown/orange, powdery spores on leaf surfaces, reducing the photosynthetic capacities of their hosts and diverting photosynthates into their own biomass (Aime et al., 2018). Important cereal crops, legumes, and trees such poplar, pine and Eucalyptus spp., are at high risk of infection from rust fungi (Figueroa et al., 2020).

Many different Puccinia species have been major culprits of numerous wheat rust epidemics worldwide, owing to their ability to spread over thousands of kilometres, across continents and oceans, via the wind (Kolmer, 2005). The first major epidemic of wheat stem rust, caused by Puccinia graminis, occurred in Ethiopia during 1993 and 1994. Since then, many other wheat rusts, like $P$. triticina (wheat leaf rust) and $P$. striiformis (stripe/yellow rust) have become more frequent in Africa, the Middle East, Asia, Australia, New Zealand, Europe and America, in the major wheat cultivating regions of the world (Singh et al., 2008). Another recent alien invasion into the Western hemisphere 
occurred in South and North America. Phakopsora pachyrhizi, the causal agent of Asian soybean rust, arrived from Asia, with Brazil bearing the highest losses - as great as an estimated US\$2 billion in 2003 (Yorinori et al., 2005). Coffee rust, caused by Hemileia vastatrix was first reported in Sri Lanka circa 1869 (Monaco, 1977) and subsequently spread across Southern India and Java, causing coffee cultivation to be terminated entirely. Another outbreak in Angola in 1966 initiated the spread of $H$. vastatrix across the Atlantic, reaching Brazil (Bowden et al., 1971). Myrtle rust, caused by Austropuccinia psidii, is a widely distributed rust disease, which infects Myrtaceae and Heteropyxidaceae plants. Austropuccinia psidii was first identified in 1884 from guava in Brazil before it spread into Central and South America, South Florida and, later, to Australia, Japan, China and South Africa, infecting numerous economically important hosts (Yamaoka, 2014). White pine blister rust, caused by Cronartium ribicola has also caused decades of epidemic conditions, decimating most of the white pine forests in the United States and Canada (Kinloch, 2003).

The current rate of climate change, which is continuously altering global temperatures, moisture levels, solar radiation levels and wind turbulence, can intensify the potential of rust fungi epidemics by influencing disease establishment and dispersal and, thereby, extending the infection range (Desprez-Loustau et al., 2007). Thus, ideal environmental conditions (especially increased moisture levels on leaf surfaces) lead to new suitable climate spaces for rust diseases. Host plant homogenisation is another inductive factor, which creates greater numbers of susceptible host individuals (Helfer, 2013). The virulence of rust pathogens can depend on temperature (Evans et al., 2007), and pathogen aggressiveness (e.g., speed and reproduction success) may also increase as hosts become more susceptible due to climate-change-induced stresses (Helfer, 2013). The global plant trade can also regularly expand the range of host plants and their rusts, while the movement of rust species globally can provide the opportunity for novel hybrid species to be generated, which can eventually give rise to new, even more destructive, host-rust relationships.

\section{Smut fungi}

Smuts (Ustilaginomycotina) belong to a heterogeneous group of fungi that parasitize plant hosts and produce teliospores as a means of reproduction (Schafer, 1987; Vánky, 2004; Bauer et al., 2008). Smut fungi are the second largest group of plant parasitic Basidiomycota. The species commonly known as smuts share similar lifecycles and cellular organisation. Smuts affect a number of economically important cereal crops, their relatives in the Poaceae family as well as some economically important non-poaceous hosts like sunflower (Asteraceae). Although smuts primarily infect panicles and seeds of cereal crops, some species infect leaves of crops and ornamental herbs, resulting in severe damage. The fungus produces slightly raised, angular, black spots (sori) on both sides of the leaves, causing severe loss of photosynthetic pigmentation. Similarly, many smuts infect commercially important crops, considerably impacting yield as well as the aesthetic nature of ornamentals.

The flag smut disease in wheat produces long, grey and black lesions on leaves and leaf sheaths and causes stunted plants with deformed tillers. The leaves of infected plants are twisted and covered with long, grey lesions, which break open to release black, powdery spores. The fungus causing flag smut, has been referred to as both Urocystis agropyri and U. tritici. Savchenko et al., (2016) identified Urocystis agropyri as a distinct taxon from $U$. tritrici, which is the cause of flag smut disease on wheat (Savchenko et al., 2016). In addition to losses in yield, wheat flag smut is quarantined in many countries, and shipments of wheat with flag smut spores can be refused entry (EPPO Global Database, 2020).

Stripe smut in grasses, caused by Ustilago striiformis s.1., is a complex of smut fungi widely distributed over both temperate and subtropical regions (Savchenko et al., 2014; Kruse et al., 2018). It is estimated that nearly 100 different grass species, belonging to more than 30 genera, are susceptible to stripe smut (Savchenko et al., 2014). This disease causes shredding and death of leaf tissue, following the rupture of elongated sori (Toh and Perlin, 2016). Rice leaf smut is caused by Entyloma oryzae, and it is a widely distributed, but somewhat minor, disease (Vanky et al., 2011, Vanky, 2012).

Among the diseases on non-poaceous hosts, sunflower white leaf smut is caused by a recently described species, Entyloma helianthi, from the United States (RooneyLatham et al., 2017). It is a relatively minor foliar disease, occurring primarily in greenhouse-grown sunflowers, which causes leaf spot, defoliation and reduced crop yield and value (Rooney-Latham et al., 2017).

Relatively fewer numbers of molecular phylogenetic studies are available for smut fungi, therefore much work is required to develop backbone phylogenetic trees and to resolve species complexes (Kruse, 2018). Smuts are significant, not only as prevalent pathogens, but also as models for other basic and practical scientific areas of investigation, including obligate biotrophy, evolution and disease invasion. Thus, the foliar smuts can cause severe loss of cereal crop production, leading to severe threats for food security both regionally and globally. Moreover, the international trade of cereal crops can be affected by unexpected issues due to the sudden emergence of unknown diseases and spread of invasive smuts across the geographic borders.

\section{Insights in to foliar fungi - impact of molecular systematics and genomics}

The past two decades have witnessed exponential growth in understanding the magnitude of fungal diversity, species numbers and their relationships, due to advances in DNA sequencing technologies and state-of-the art analytical methods (Blackwell et al., 2006; Crous et al., 2015). Molecular systematics is using promising tools to reveal the unexplored fungal diversity associated with plants as pathogens, saprobes, endophytes and other mutualistic species. DNA-based taxonomy has allowed mycologists to 
resolve cryptic diversity in the species-rich genera of fungi, such as Alternaria, Bipolaris, Curvularia, Colletotrichum, Diaporthe, Fusarium and Neopestalotiopsis, which include large numbers of foliar pathogens. Large numbers of available nuclear ribosomal internal transcribed spacer region (ITS) fungal barcode sequences in GenBank, as well as other curated fungal DNA sequence repositories such as UNITE (Kõljalg et al., 2013 https://unite.ut.ee/), have facilitated the plant pathology field and other interdisciplinary areas related to fungal research (Nilsson et al., 2014). Multi-gene phylogenies of leaf-inhabiting genera have been used to resolve many species complexes in fungi, combined with a consolidated approach to species recognition criteria, including morphological, biochemical, physiological and pathogenicity data. Phylogenetic reconstructions not only resolve the evolution of pathogens, but can also be used to develop predictive tools for phytosanitary risk analysis in crop protection and biosecurity (Gilbert et al., 2012; Gilbert and Parker, 2016).

The genomic data of plant pathogenic fungi generated by high-throughput DNA sequencing platforms could reveal reliable DNA markers for disease diagnostics, genes related to pathogenicity such as carbohydrate-degrading enzymes, fungal effector proteins, various secondary metabolites and toxins (Islam et al., 2012; McGrann et al., 2016; Juliana et al., 2018). The phylogenetic reconstructions based on the analysis of full genomes or at least large portions of them, have resulted in more robust phylogenies of various genera and higher level taxa of fungi (Kuramae et al., 2006; Luo et al., 2015; Whiston and Taylor, 2016). The genome data of representatives from the key foliar fungal groups, including Colletotrichum spp. (O'Conell et al., 2012), diaporthalean fungi (Wu et al., 2020), Dothideomycetes (Haridas et al., 2010), powdery mildews (Frantzeskakis et al., 2019), rusts (Hacquard et al., 2012; Gill et al., 2019) and smuts (Benevenuto et al., 2018) are available from several recent studies. Thus, comparative genomic analyses have revealed essential information, which can be used to form epidemiological predictions, to understand host resistance and pathogen evolution related to potential outbreaks (Xue et al., 2012; Kuan et al., 2015). Overall, molecular systematics and genomics have significantly improved the present understanding of foliar pathogens, leading to accurate identification, disease surveillance and implementation of effective disease management.

\section{CONCLUSIONS}

Globally, foliar diseases in plants are growing threats to agriculture, food security, biodiversity and the ecological balance of the natural environment. Pathogenic fungal species that cause foliar diseases are highly taxonomically diverse. Although some foliar pathogens only minorly impact plants, it is highly likely that a similar pathogen may cause destructive diseases, leading to regional and global threats. Therefore, emerging or invasive species of foliar pathogens should not be underestimated, especially when encountered on economically important hosts and new geographic regions. Evolutionary relationships inferred by molecular data, as well as understanding the disease epidemiology and genomics of the pathogens, provide information about disease spread, which necessitates predictions concerning potential outbreaks and epidemics.

\section{ACKNOWLEDGEMENTS}

University of Sri Jayewardenepura is thanked for facilitating ongoing research in Applied Mycology and Plant Health. DU and DSM acknowledge the United States Department of Agriculture-Agricultural Research Service (USDA-ARS), Beltsville, Maryland, USA and the Research Participation Program, administered by the Oak Ridge Institute for Science and Education for the postdoctoral fellowships during 2015-2017.

\section{DECLARATION OF CONFLICT OF INTEREST}

The authors declare no conflict of interest.

\section{REFERENCES}

Adams, G.C., Roux, J. and Wingfield, M.J. (2006). Cytospora species (Ascomycota, Diaporthales, Valsaceae): introduced and native pathogens of trees in South Africa. Australasian Plant Pathology 35(5): 521548. DOI: https://doi.org/10.1071/AP06058.

Aime, M.C., Bell, C.D. and Wilson, A.W. (2018). Deconstructing the evolutionary complexity between rust fungi (Pucciniales) and their plant hosts. Studies in Mycology 89: 143-152. DOI: https://doi.org/10.1016/j. simyco.2018.02.002.

Aime, M.C., Matheny, P.B., Henk, D.A., Frieders, E.M., Nilsson, R.H., Piepenbring, M., Maclaughlin, D.J., Szabo, L.J., Bigero, D., Sampaio, J.P. and Bauer, R. (2006). An overview of the higher level classification of Pucciniomycotina based on combined analyses of nuclear large and small subunit rDNA sequences. Mycologia 98(6): 896-905. DOI: https://doi.org/10.10 80/15572536.2006.11832619.

Aime, M.C., Toome, M. and McLaughlin, D.J. (2014). Pucciniomycotina. In: D.J. McLaughlin and J. W. Spatafora (Eds.), The Mycota:Systematics and Evolution, Springer-Verlag, Heidelberg Pp. 271-294. DOI: https://doi.org/10.1007/978-3-642-55318-9_10.

Alahakoon, P.W., Brown, A.E. and Sreenivasaprasad, S. (1994). Cross-infection potential of genetic groups of Colletotrichum gloeosporioides on tropical fruits. Physiological and Molecular Plant Pathology 44(2): 93-103. DOI: https://doi.org/10.1016/S08855765(05)80104-3.

Alam, K. and Rolfe, J. (2006). Economics of plant disease outbreaks. Agenda: A Journal of Policy Analysis and Reform 13(2): 133-146.

Ale-Agha, N., Braun, U., Feige, B. and Jage, H. (2000). A new powdery mildew disease on Aesculus spp. introduced in Europe. Cryptogamie Mycologie 21(2):89-92. DOI: https://doi.org/10.1016/S01811584(00)00117-2.

Allen, E.A. and Humble, L.M. (2002). Nonindigenous species introductions: a threat to Canada's forests and forest economy1. Canadian Journal of Plant Pathology 24(2): 103-110. DOI: https://doi. org/10.1080/07060660309506983.

Allioui, N., Siah, A., Brinis, L., Reignault, P. and Halama, 
P. (2016). Identification of QoI fungicide-resistant genotypes of the wheat pathogen Zymoseptoria tritici in Algeria. Phytopathologia Mediterranea 55(1): 89-97. DOI: https://doi.org/10.14601/Phytopathol_ Mediterr-16235.

Amaradasa, B.S., Madrid, H., Groenewald, J.Z., Crous, P.W. and Amundsen, K. (2014). Porocercospora seminalis gen. et comb. nov., the causal organism of buffalo grass false smut. Mycologia 106(1): 77-85.

Amico, A. L., Ituarte-Lima, C. and Elmqvist, T. (2020). Learning from social-ecological crisis for legal resilience building: multi-scale dynamics in the coffee rust epidemic. Sustainability Science 15(2): 485-501. DOI: https://doi.org/10.1007/s11625-019-00703-x.

Anagnostakis, S. L. (1987). Chestnut blight: the classical problem of an introduced pathogen. Mycologia 79(1): 23-37. DOI: https://doi.org/10.1080/00275514.1987.12 025367.

Arnold, A.E. (2007). Understanding the diversity of foliar endophytic fungi: progress, challenges and frontiers. Fungal Biology Reviews 21: 51-56. DOI: https://doi. org/10.1016/j.fbr.2007.05.003

Arthur, J. C. (1934). Manual of the rusts in United States and Canada. Purdue Research Foundation, Lafayette, 438.

Avelino, J., Cristancho, M., Georgiou, S., Imbach, P., Aguilar, L., Bornemann, G., Läderach, P., Anzueto, F., Hruska, A.J. and Morales, C. (2015). The coffee rust crises in Colombia and Central America (2008-2013): impacts, plausible causes and proposed solutions. Food Security 7(2): 303-321. DOI: https://doi.org/10.1007/ s12571-015-0446-9

Barón, M., Flexas, J. and Delucia, E.H. (2012). Photosynthetic responses to biotic stress. In: J. Flexas, F. Loreto and H. Medrano (Eds.), Terrestrial Photosynthesis in a changing environment: A molecular, morphological and physiological approach, Cambridge University Press Pp. 331-350.

Bauer, R., Lutz, M., Begerow, D., Piątek, M., Vánky, K., Bacigálová, K. and Oberwinkler, F. (2008). Anther smut fungi on monocots. Mycological Research 112(11): 1297-1306. DOI: https://doi.org/10.1016/j. mycres.2008.06.002.

Benevenuto, J., Teixeira-Silva, N.S., Kuramae, E.E., Croll, D. and Monteiro-Vitorello, C.B. (2018). Comparative genomics of smut pathogens: insights from orphans and positively selected genes into host specialization. Frontiers in Microbiology 9: 660. DOI: https://doi. org/10.3389/fmicb.2018.00660

Blackwell, M., Hibbett, D. S., Taylor, J.W. and Spatafora, J.W. (2006). Research coordination networks: a phylogeny for kingdom Fungi (Deep Hypha). Mycologia 98(6):829-837. DOI: http://dx.doi.org/10.3852/ mycologia.98.6.829

Bowden, J., Gregory, P.H. and Johnson, C.G. (1971). Possible wind transport of coffee leaf rust across the Atlantic Ocean. Nature 229 (5285): 500-501. DOI: https://doi.org/10.1038/229500b0

Braun, U. (2011). The current systematics and taxonomy of the powdery mildews (Erysiphales): an overview. Mycoscience 52(3):210-212. DOI: https://doi.
org/10.1007/S10267-010-0092-1

Brewer, L.G. (1995). Ecology of survival and recovery from blight in American chestnut trees (Castanea dentata (Marsh.) Borkh.) in Michigan. Bulletin of the Torrey Botanical Club 122(1): 40-57. DOI: https:// www.jstor.org/stable/299640.

Broom, F. (2020). The next pandemic is coming - now is the time to unite, SCIDEV.net. Available from: https:// www.scidev.net/global/health/editorials/the-nextpandemic-is-coming-now-is-the-time-to-unite.html

Cai, L., Hyde, K.D., Taylor, P.W.J., Weir, B., Waller, J., Abang, M.M., Zhang, J.Z. and Yang, Y.L., Phoulivong, S., Liu, Z.Y. and Prihastuti, H. (2009). A polyphasic approach for studying Colletotrichum. Fungal Diversity 39(1): 183-204..

Callan, B.E., and Carris, L.M. (2004). Fungi on living plant substrata, including fruits. In: G.M. Mueller, G.F. Bills and M.S. Foster (Eds.), Biodiversity of Fungi-Inventory and Monitoring Methods, Elsevier Academic Press, Burlington Pp. 105-126.

Cannon, P., Damm, U., Johnston, P. and Weir, B. (2012). Colletotrichum - current status and future directions. Studies in Mycology 73: 181-213. DOI: https://doi. org/10.3114/sim0014

Cao, X., Xu, X., Che, H., West, J.S. and Luo, D. (2019). Three Colletotrichum species, including a new species, are associated to leaf anthracnose of rubber tree in Hainan, China. Plant Disease 103(1): 117-124. DOI: https://doi.org/10.1094/PDIS-02-18-0374-RE.

Castlebury, L.A., Rossman, A.Y., Jaklitsch, W.J. and Vasilyeva, L.N. (2002). A preliminary overview of the Diaporthales based on large subunit nuclear ribosomal DNA sequences. Mycologia 94(6): 1017-1031. DOI: https://doi.org/10.2307/3761867.

Chaliha, C., Kalita, E. and Verma, P.K. (2019). Optimizing in vitro culture conditions for the biotrophic fungi Exobasidium vexans through Response Surface Methodology. Indian Journal of Microbiology 60: 167174. DOI: https://doi.org/10.1007/s12088-019-008466.

Chaure, P., Gurr, S.J. and Spanu, P. (2000). Stable transformation of Erysiphe graminis an obligate biotrophic pathogen of barley. Nature Biotechnology 18(2): 205-207. DOI: https://doi.org/10.1038/72666.

Chen, Y.J., Meng, Q., Zeng, L. and Tong, H.R. (2018). Phylogenetic and morphological characteristics of Alternaria alternata causing leaf spot disease on Camellia sinensis in China. Australasian Plant Pathology 47(3):335-342. DOI: https://doi.org/10.1007/ s13313-018-0561-0.

Chen, Y., Yang, L.N., Bai, Q.R., Song, T.Y., Wu, C.Y. and Liu, S.Y. (2017). First report of powdery mildew caused by Podosphaera xanthii on Ligularia fischeri in China. Plant Disease 101(7): 1321-1322. DOI: https:// doi.org/10.1094/PDIS-02-17-0209-PDN

Cho, S.E., Choi, I.Y., Han, K.-S. and Shin, H.D. (2017). First records of Podosphaera xanthii on Peperomia tetragona. Australasian Plant Disease Notes 12: 31. DOI: https://dx.doi.org/10.1007/s13314-017-0257-2

Colhoun, J. (1973). Effects of environmental factors on plant disease. Annual Review of Phytopathology 
11(1):343-364. DOI: https://doi.org/10.1146/annurev. py.11.090173.002015.

Couch, B.C. and Kohn, L.M. (2002). A multilocus gene genealogy concordant with host preference indicates segregation of a new species, Magnaporthe oryzae, from M. grisea. Mycologia 94(4): 683-693. DOI: https://doi.org/10.1080/15572536.2003.11833196.

Crouch, J.A., Beirn, L.A., Cortese, L.M., Bonos, S.A.and Clarke, B.B. (2009). Anthracnose disease of switchgrass caused by the novel fungal species Colletotrichum navitas. Mycological Research 113: 1411-1421. DOI: https://doi.org/10.1016/j.mycres.2009.09.010.

Crous, P.W., Hawksworth, D.L. and Wingfield, M.J. (2015). Identifying and naming plant-pathogenic fungi: past, present, and future. Annual Review of Phytopathology 53: 247-267. DOI: https://doi.org/10.1146/annurevphyto-080614-120245.

Crous, P.W., Summerell, B.A., Carnegie, A.J., Wingfield, M.J. and Groenewald, J.Z. (2009). Novel species of Mycosphaerellaceae and Teratosphaeriaceae. Persoonia 23: 119-146. DOI: https://doi. org/10.3767/003158509X479531.

Crous, P.W., Wingfield, M.J., Cheewangkoon, R., Carnegie, A.J., Burgess, T.I., Summerell, B.A., Edwards, J., Taylor, P.W.J. and Groenewald, J.Z. (2019). Foliar pathogens of eucalypts. Studies in Mycology 94: 125-298. DOI: https://doi.org/10.1016/j.simyco.2019.08.001.

Damm, U., Baroncelli, R., Cai, L., Kubo, Y., O’Connell, R., Weir, B., Yoshino, K. and Cannon, P.F. (2010). Colletotrichum: species, ecology and interactions. IMA Fungus 1(2): 161-165. DOI: https://doi.org/10.5598/ imafungus.2010.01.02.08.

Damm, U., Cannon, P.F., Woudenberg, J.H.C. and Crous, P.W. (2012a). The Colletotrichum acutatum species complex. Studies in Mycology 73: 37-113. DOI: https:// doi.org/10.3114/sim0010

Damm, U., Cannon, P.F., Woudenberg, J.H.C., Johnston, P.R., Weir, B., Tan, Y., Shivas, R.G. and Crous, P.W. (2012b). The Colletotrichum boninense species complex. Studies in Mycology 73: 1-36. DOI: https:// doi.org/10.3114/sim0002.

Daughtrey, M.L. (2019). Boxwood blight: Threat to ornamentals. Annual Review of Phytopathology 57: 189-209. DOI: https://doi.org/10.1146/annurevphyto-082718-100156.

De Silva, D.D., Ades, P.K., Crous, P.W. and Taylor, P.W.J. (2017). Colletotrichum species associated with chili anthracnose in Australia. Plant Pathology 66: 254-267. DOI: https://doi.org/10.1111/ppa.12572.

Dean, R., Van Kan, J.A., Pretorius, Z.A., HammondKosack, K.E., Di Pietro, A., Spanu, P.D., Rudd, J.J., Dickman, M., Kahmann, R., Ellis, J. and Foster, G.D. (2012). The Top 10 fungal pathogens in molecular plant pathology. Molecular Plant Pathology 13(4): 414-430. DOI: https://doi.org/10.1111/j.1364-3703.2011.00783.x

Desprez-Loustau, M.L., Robin, C., Reynaud, G., Déqué, M., Badeau, V., Piou, D., Husson, C. and Marcais, B. (2007). Simulating the effects of a climate-change scenario on the geographical range and activity of forest-pathogenic fungi. Canadian Journal of Plant Pathology 29(2): 101-120. DOI: https://doi. org/10.1080/0706066070950744.

Duan, W., Duan, L., Chen, X. and Cai, L. (2016). Identification of the quarantine fungus Diaporthe helianthi from the corn seeds imported from Ukraine. Mycosystema 35(12): 1503-1513.

du Plessis, E., Granados, G.M., Barnes, I., Ho, W.H., Alexander, B.J.R., Roux, J. and McTaggart, A.R. (2019). The pandemic strain of Austropuccinia psidii causes myrtle rust in New Zealand and Singapore. Australasian Plant Pathology 48(3): 253-256. DOI: https://doi.org/10.1007/s13313-019-0624-x.

Duveiller, E. and Gilchrist, L. (1994). Production constraints due to Bipolaris sorokiniana in wheat: current situation and future prospects. In: D.A. Saunders and G.P. Hettel (Eds.), Wheat in heat-stressed environments: irrigated, dry areas and rice-wheat farming systems, International Maize and Wheat Improvement Center, Mexico Pp. 343-352.

Elad, Y. and Pertot, I. (2014). Climate change impacts on plant pathogens and plant diseases. Journal of Crop Improvement 28(1): 99-139. DOI: https://doi.org/10.10 80/15427528.2014.865412.

Ellis, M.B. (1971). Dematiaceous hyphomycetes. Commonwealth Mycological Institute, Kew, 608.

EPPO: Global Database of European and Mediterranean Plant Protection Organization. (2020). Available from: https://gd.eppo.int/taxon/UROCAG.

Evans, N., Baierl, A., Semenov, M.A., Gladders, P. and Fitt, B.D. (2007). Range and severity of a plant disease increased by global warming. Journal of the Royal Society Interface 5(22): 525-531. DOI: https://doi. org/10.1098/rsif.2007.1136.

Farr, D.F. and Rossman, A.Y. Fungal Databases, U.S. National Fungus Collections, ARS, USDA. Retrieved September 5, 2020, from https://nt.ars-grin.gov/ fungaldatabases/.

Feau, N., Vialle, A., Allaire, M., Tanguay, P., Joly, D.L., Frey, P., Callan, B.E. and Hamelin, R.C. (2009). Fungal pathogen (mis-) identifications: a case study with DNA barcodes on Melampsora rusts of aspen and white poplar. Mycological Research 113: 713-724. DOI: https://doi.org/10.1080/15572536.2006.11832696.

Figueroa, M., Dodds, P.N. and Henningsen, E.C. (2020). Evolution of virulence in rust fungi-multiple solutions to one problem. Current Opinion in Plant Biology 56: 20-27. DOI: https://doi.org/10.1016/j.pbi.2020.02.007.

Fisher, M.C., Henk, D. A., Briggs, C. J., Brownstein, J.S., Madoff, L. C., McCraw, S.L. and Gurr, S.J. (2012). Emerging fungal threats to animal, plant and ecosystem health. Nature 484(7393): 186-194. DOI: https://doi. org/10.1038/nature10947.

Frantzeskakis, L., Németh, M.Z., Barsoum, M., Kusch, S., Kiss, L., Takamatsu, S. and Panstruga, R. (2019). The Parauncinula polyspora draft genome provides insights into patterns of gene erosion and genome expansion in powdery mildew fungi. mBio 10(5): .e01692-19. DOI: https://doi.org/10.1128/mBio.01692-19.

Fullerton, R.A. and Casonato, S.G. (2019). The infection of the fruit of 'Cavendish'banana by Pseudocercospora fijiensis, cause of black leaf streak (black Sigatoka). European Journal of Plant Pathology 155(3): 779-787. 
DOI: https://doi.org/10.1007/s10658-019-01807-x.

Gauthier, N. and Dockery, J. (2018). Boxwood Blight. Plant Pathology Fact Sheets:PPFS-OR-W-20. Available from: http://plantpathology.ca.uky.edu/files/ ppfs-or-w-20.pdf

Gilbert, G.S. and Parker, I.M. (2016). The evolutionary ecology of plant disease: a phylogenetic perspective. Annual Review of Phytopathology 54: 549-578. DOI: https://doi.org/10.1146/annurev-phyto-102313-045959

Gilbert, G.S., Magarey, R., Suiter, K. and Webb, C.O. (2012). Evolutionary tools for phytosanitary risk analysis: phylogenetic signal as a predictor of host range of plant pests and pathogens. Evolutionary Applications 5(8):869-878. DOI: https://doi.org/10.1111/j.17524571.2012.00265.x

Gill, U.S., Nandety, R.S., Krom, N., Dai, X., Zhuang, Z., Tang, Y., Zhao, P.X. and Mysore, K.S. (2019). Draft Genome Sequence Resource of Switchgrass Rust Pathogen, Puccinia novopanici Isolate Ard-01. Phytopathology 109(9) :1513-1515. DOI: https://doi. org/10.1094/PHYTO-04-19-0118-A

Gomes, R.R., Glienke, C., Videira, S.I.R., Lombard, L., Groenewald, J.Z. and Crous, P.W. (2013). Diaporthe: a genus of endophytic, saprobic and plant pathogenic fungi. Persoonia: Molecular Phylogeny and Evolution of Fungi 31(1): 1-41. DOI: https://doi. org/10.3767/003158513X666844

González-Lamothe, R., Segura, R., Trapero, A., Baldoni, L., Botella, M.A. and Valpuesta, V. (2002). Phylogeny of the fungus Spilocaea oleagina, the causal agent of peacock leaf spot in olive. FEMS Microbiology Letters 210(1): 149-155. DOI: https://doi. org/10.1111/j.1574-6968.2002.tb11174.x

Gryzenhout, M., Myburg, H., Wingfield, B.D. and Wingfield, M.J. (2006). Cryphonectriaceae (Diaporthales), a new family including Cryphonectria, Chrysoporthe, Endothia and allied genera. Mycologia 98(2):239-249. DOI: https://doi.org/10.1080/15572536 .2006 .11832696

Guarnaccia, V., Groenewald, J.Z., Woodhall, J., Armengol, J., Cinelli, T., Eichmeier, A., and Kaliterna, J. (2018). Diaporthe diversity and pathogenicity revealed from a broad survey of grapevine diseases in Europe. Persoonia: Molecular Phylogeny and Evolution of Fungi 40:135. DOI: https://doi.org/10.3767/persoonia.2018.40.06

Hacquard, S., Joly, D.L., Lin, Y.C., Tisserant, E., Feau, N., Delaruelle, C., Legué, V., Kohler, A., Tangyay, P., Petre, B., Peer, Y.V., Rouzé, P., Martin, F., Hamelin, R.C and Frey, P. (2012). A comprehensive analysis of genes encoding small secreted proteins identifies candidate effectors in Melampsora larici-populina (poplar leaf rust). Molecular Plant-Microbe Interactions 25(3):279293. DOI: https://doi.org/10.1094/MPMI-09-11-0238

Haq, I.U., Sarwar, M.K., Faraz, A. and Latif, M.Z. (2020). Synthetic Chemicals: Major Component of Plant Disease Management. In: I.U. Haq and S. Ijaz (Eds.), Plant Disease Management Strategies for Sustainable Agriculture through Traditional and Modern Approaches, Springer, Cham, Switzerland Pp. 538. DOI: https://doi.org/10.1007/978-3-030-35955-3_4

Haridas, S., Albert, R., Binder, M., Bloem, J., LaButti,
K., Salamov, A., Andreopoulos, B., Baker, S.E., Barry, K., Bills, G. and Bluhm, B.H. (2020). 101 Dothideomycetes genomes: a test case for predicting lifestyles and emergence of pathogens. Studies in Mycology 96:141-153. DOI: https://doi.org/10.1016/j. simyco.2020.01.003

Harrat, W., Meamiche Neddaf, H., Keddad, A. and Bouznad, Z. (2017). First report of the Zymoseptoria tritici teleomorph stage causing septoria leaf blotch of wheat in Algeria. New Disease Reports 35:30. DOI: http://dx.doi.org/10.5197/j.2044-0588.2017.035.030

Hawksworth, D.L. and Rossman, A.Y. (1997). Where are all the undescribed fungi?. Phytopathology 87(9):888-891. DOI: https://doi.org/10.1094/PHYTO.1997.87.9.888

Hawksworth, D.L. (2001). The magnitude of fungal diversity: the 1.5 million species estimate revisited. Mycological Research 105(12):14225-1432. DOI: https://doi.org/10.1017/S0953756201004725

Helfer, S. (2013). Rust fungi and global change. New Phytologist 201(3):770-780. DOI: https://doi. org/10.1111/nph.12570

Hernandez-Restrepo, M., Madrid, H., Tan, Y.P., Da Cunha, K.C., Gene, J., Guarro, J. and Crous, P. W. (2018). Multi-locus phylogeny and taxonomy of Exserohilum. Persoonia: Molecular Phylogeny and Evolution of Fungi 41:71. DOI: https://doi.org/10.3767/ persoonia.2018.41.05

Hibbett, D., Abarenkov, K., Kõljalg, U., Öpik, M., Chai, B., Cole, J., Wang, Q., Crous, P., Robert, V., Helgason, T. and Herr, J.R. (2016). Sequence-based classification and identification of Fungi. Mycologia 108(6):10491068. DOI: https://doi.org/10.3852/16-130

Horvath, D. (2020). Guest Commentary - The Next Pandemic Could Attack Our Crops. The Chicago Council on Global Affairs. Available from: https:// www.thechicagocouncil.org/blog/global-food-thought/ guest-commentary-next-pandemic-could-attack-ourcrops

Howard, R.J. and Valent, B. (1996). Breaking and entering: host penetration by the fungal rice blast pathogen Magnaporthe grisea. Annual Review of Microbiology 50:491-513. DOI: https://doi.org/10.1146/annurev. micro.50.1.491

Huber, L. and Gillespie, T.J. (1992). Modeling leaf wetness in relation to plant disease epidemiology. Annual Review of Phytopathology 30(1):553-577. DOI: https:// doi.org/10.1146/annurev.py.30.090192.003005

Hunupolagama, D.M., Chandrasekharan, N.V., Wijesundera, W.S.S., Kathriarachchi, H.S., Fernando, T.H.P.S. and Wijesundera, R.L.C. (2017). Unveiling Members of Colletotrichum acutatum Species Complex Causing Colletotrichum Leaf Disease of Hevea brasiliensis in Sri Lanka. Current Microbiology 74(6):747-756. DOI: https://doi.org/10.1007/s00284017-1238-6

Hyde, K.D., Cai, L., McKenzie, E.H.C., Yang, Y.L., Zhang, J.Z. and Prihastuti, H. (2009). Colletotrichum: a catalogue of confusion. Fungal Diversity 39(1):1-17.

Inuma, T., Khodaparast, S.A. and Takamatsu, S. (2007). Multilocus phylogenetic analyses within Blumeria graminis, a powdery mildew fungus of cereals. 
Molecular Phylogenetics and Evolution 44(2): 741-751. DOI: https://doi.org/10.1016/j.ympev.2007.01.007.

Islam, M.S., Haque, M.S., Islam, M.M., Emdad, E.M., Halim, A., Hossen, Q.M.M., ... and Alam, M.M. (2012). Tools to kill: genome of one of the most destructive plant pathogenic fungi Macrophomina phaseolina. BMC Genomics 13(1):493.

Ito, M. and Takamatsu, S. (2010). Molecular phylogeny and evolution of subsection Magnicellulatae (Erysiphaceae: Podosphaera) with special reference to host plants. Mycoscience 51(1):34-43. DOI: https://doi. org/10.1007/S10267-009-0005-3.

Jayasinghe, C.K., Fernando, T.H.P.S. and Priyanka, U.M.S. (1997) Colletotrichum acutatum is the main cause of Colletotrichum leaf disease of rubber in Sri Lanka. Mycopathologia 137:53-56. DOI: https://doi. org/10.1023/A:1006850119146.

Johnston, P.R., Seifert K. A., Stone, J.K., Rossman, A.Y. and Marvanova, L. (2014). Recommendations on generic names competing for use in Leotiomycetes (Ascomycota). IMA Fungus 5:91-120. DOI: https://doi. org/10.5598/imafungus.2014.05.01.11

Juliana, P., Singh, R.P., Singh, P.K., Poland, J.A., Bergstrom, G.C., Huerta-Espino, J., ... and Sorrells, M.E. (2018). Genome-wide association mapping for resistance to leaf rust, stripe rust and tan spot in wheat reveals potential candidate genes. Theoretical and Applied Genetics 131(7):1405-1422. DOI: https://doi. org/10.1007/s00122-018-3086-6.

Kačergius, A. and Jovaišienè, Z. (2.010). Molecular characterization of quarantine fungus Diaporthe/ Phomopsis vaccinii and related isolates of Phomopsis from Vaccinium plants in Lithuania. Botanica Lithuanica 16(4):177-182.

Khan, M.A.I., Ali, M.A., Monsur, M.A., Kawasaki-Tanaka, A., Hayashi, N., Yanagihara, S., Obara, M., Mia, M.A.T., Latif, M.A. and Fukuta, Y. (2016). Diversity and distribution of rice blast (Pyricularia oryzae Cavara) races in Bangladesh. Plant Disease 100(10):2025-2033. DOI: https://doi.org/10.1094/PDIS-12-15-1486-RE.

Kinloch Jr, B.B. (2003). White pine blister rust in North America: past and prognosis. Phytopathology 93(8):1044-1047. DOI: https://doi.org/10.1094/ PHYTO.2003.93.8.1044.

Kiss, L. (2005). Powdery mildew as invasive plant pathogens: new epidemics caused by two North American species in Europe. Mycological Research 109(3):259-260. DOI: https://doi.org/10.1017/ S0953756205232793.

Klaubauf, S., Tharreau, D., Fournier, E., Groenewald, J.Z., Crous, P.W., de Vries, R.P. and Lebrun, M.H. (2014). Resolving the polyphyletic nature of Pyricularia (Pyriculariaceae). Studies in Mycology 79:85-120. DOI: https://doi.org/10.1016/j.simyco.2014.09.004.

Klinkowski, M. (1970). Catastrophic plant diseases. Annual Review of Phytopathology 8(1):37-60. DOI: https://doi. org/10.1146/annurev.py.08.090170.000345.

Kõljalg, U., Nilsson, R.H., Abarenkov, K., Tedersoo, L., Taylor, A.F., Bahram, M., Bates, S.T., Bruns, T.D., Bengtsson-Palme, J., Callaghan, T.M. and Douglas, B. (2013). Towards a unified paradigm for sequence-based identification of fungi. Molecular Ecology 22(21):52715277. DOI: https://doi.org/10.1111/mec.12481.

Kolmer, J.A. (2005). Tracking wheat rust on a continental scale. Current Opinion in Plant Biology 8(4):441-449. DOI: https://doi.org/10.1016/j.pbi.2005.05.001.

Kolmer, J.A. (2015). First report of a wheat leaf rust (Puccinia triticina) phenotype with high virulence to durum wheat in the Great Plains region of the United States. Plant Disease 99(1): 156-156. DOI: https://doi. org/10.1094/PDIS-06-14-0667-PDN.

Kruse, J.M. (2018). The Phylogeny of Smut Fungi (Ustilaginomycotina) ( $\mathrm{PhD}$ dissertation). Johann Wolfgang Goethe University, Frankfurt am Main, Germany.

Kruse, J., Dietrich, W., Zimmermann, H., Klenke, F., Richter, U., Richter, H. and Thines, M. (2018). Ustilago species causing leaf-stripe smut revisited. IMA Fungus 9(1):49-73. DOI: https://doi.org/10.5598/ imafungus.2018.09.01.05.

Kuan, C.S., Yew, S.M., Toh, Y.F., Chan, C.L., Ngeow, Y.F., Lee, K.W., Na, S.L., Yee, W.Y., Hoh, C.C. and Ng, K.P. (2015). Dissecting the fungal biology of Bipolaris papendorfii: from phylogenetic to comparative genomic analysis. DNA Research 22(3):219-232. DOI: https:// doi.org/10.1093/dnares/dsv007.

Kuramae, E. E., Robert, V., Snel, B., Weiß, M. and Boekhout, T. (2006). Phylogenomics reveal a robust fungal tree of life. FEMS Yeast Research 6(8):1213-1220. DOI: https://doi.org/10.1111/j.1567-1364.2006.00119.x

LeBlanc, N., Salgado-Salazar, C. and Crouch, J.A. (2018). Boxwood blight: an ongoing threat to ornamental and native boxwood. Applied Microbiology and Biotechnology 102(10):4371-4380. DOI: https://doi. org/10.1007/s00253-018-8936-2

Li, M., Li, R., Yan, H.F. and Liu, D.Q. (2019). First report of Bipolaris sorokiniana causing leaf spot on Avena nuda in China. Plant Disease 103(10):2667. DOI: https://doi. org/10.1094/PDIS-05-19-1060-PD.

Liang, J., Li, G., Zhao, M. and Cai, L. (2019). A new leaf blight disease of turf grasses caused by Microdochium poae, sp. nov. Mycologia 111(2):265-273. DOI: https:// doi.org/10.1080/00275514.2019.1569417

Liu, X., Li, B., Cai, J., Zheng, X., Feng, Y. and Huang, G. (2018). Colletotrichum Species Causing Anthracnose of Rubber Trees in China. Scientific Reports 8(1). DOI: https://doi.org/10.1038/s41598-018-28166-7.

Lobato, A.K.S., Gonçalves-Vidigal, M.C., Vidigal Filho, P.S., Andrade, C.A.B., Kvitschal, M. V. and Bonato, C. M. (2010). Relationships between leaf pigments and photosynthesis in common bean plants infected by anthracnose. New Zealand Journal of Crop and Horticultural Science 38(1):29-37. DOI: https://doi. org/10.1080/01140671003619308.

Luo, J., Qiu, H., Cai, G., Wagner, N.E., Bhattacharya, D. and Zhang, N. (2015). Phylogenomic analysis uncovers the evolutionary history of nutrition and infection mode in rice blast fungus and other Magnaporthales. Scientific Reports 5:9448. DOI: https://doi.org/10.1038/ srep09448.

Mabbett, T. (2016). Epidemiology and management of Exobasidium vexans (blister blight disease) on Camellia 
sinensis (tea). International Pest Control 58(2):114.

Macedo, D.M., Lelis, T.P., and Barreto, R.W. (2016). Bipolaris maydis causing leaf blight on Rottboellia cochinchinensis in Brazil: A major crop pathogen on a major weed. Plant Disease 100(1):215. DOI: https:// doi.org/10.1094/PDIS-05-15-0576-PDN.

Malapi-Wight, M., Hébert, J.B., Buckley, R., Daughtrey, M.L., Gregory, N.F., Rane, K., Tirpak, S. and Crouch, J.A. (2014). First report of boxwood blight caused by Calonectria pseudonaviculata in Delaware, Maryland, New Jersey, and New York. Plant Disease 98(5): 698. DOI: https://doi.org/10.1094/PDIS-10-13-1102-PDN.

Manamgoda, D.S., Cai, L., Bahkali, A.H., Chukeatirote, E. and Hyde, K.D. (2011). Cochliobolus: an overview and current status of species. Fungal Diversity 51(1):3-42. DOI: https://doi.org/10.1007/s13225-011-0139-4.

Manamgoda, D.S., Cai, L., McKenzie, E.H., Crous, P.W., Madrid, H., Chukeatirote, E., Shivas, R.G., Tan, Y.P. and Hyde, K.D. (2012). A phylogenetic and taxonomic re-evaluation of the Bipolaris-Cochliobolus-Curvularia complex. Fungal Diversity 56(1):131-144. DOI: https://doi.org/10.1007/s13225-012-0189-2.

Manamgoda, D.S., Rossman, A.Y., Castlebury, L.A., Chukeatirote, E. and Hyde, K.D. (2015). A taxonomic and phylogenetic re-appraisal of the genus Curvularia (Pleosporaceae): human and plant pathogens. Phytotaxa 212(3):175-198. DOI: https://doi.org/10.11646/ phytotaxa.212.3.1.

Manamgoda, D.S., Rossman, A.Y., Castlebury, L.A., Crous, P.W., Madrid, H., Chukeatirote, E. and Hyde, K.D. (2014). The genus Bipolaris. Studies in Mycology 79:221-288. DOI: https://doi.org/10.1016/j. simyco.2014.10.002

Manzo-Sánchez, G., Orozco-Santos, M., Islas-Flores, I., Martínez-Bolaños, L., Guzmán-González, S., Leopardi-Verde, C.L. and Canto-Canché, B. (2019). Genetic variability of Pseudocercospora fijiensis, the black Sigatoka pathogen of banana (Musa spp.) in Mexico. Plant Pathology 68(3):513-522. DOI: https:// doi.org/10.1111/ppa.12965.

Marin, D.H., Romero, R.A., Guzmán, M. and Sutton, T.B. (2003). Black Sigatoka: an increasing threat to banana cultivation. Plant Disease 87(3):208-222. DOI: https:// doi.org/10.1094/PDIS.2003.87.3.208.

Marin-Felix, Y., Groenewald, J.Z., Cai, L., Chen, Q., Marincowitz, S., Barnes, I., and De Beer, Z.W. (2017). Genera of phytopathogenic fungi: GOPHY 1. Studies in Mycology 86:99-216. DOI: https://doi.org/10.1016/j. simyco.2019.05.001

Marin-Felix, Y., Hernández-Restrepo, M. and Crous, P.W. (2020). Multi-locus phylogeny of the genus Curvularia and description of ten new species. Mycological Progress 19:559-588. DOI: https://doi.org/10.1007/ s11557-020-01576-6.

McDermott, J.M. and McDonald, B. A. (1993). Gene flow in plant pathosystems. Annual Review of Phytopathology 31(1):353-373. DOI: https://doi.org/10.1146/annurev. py.31.090193.002033.

McGrann, G.R., Andongabo, A., Sjökvist, E., Trivedi, U., Dussart, F., Kaczmarek, M., ... and Gorniak, K. (2016). The genome of the emerging barley pathogen
Ramularia collo-cygni. BMC Genomics 17(1):1-17. DOI: https://doi.org/10.1186/s12864-016-2928-3.

Milazzo, J., Pordel, A., Ravel, S. and Tharreau, D. 2019. First scientific report of Pyricularia oryzae causing gray leaf spot disease on perennial ryegrass Lolium perenne in France. Plant Disease 103(5):1024. DOI: https://doi.org/10.1094/PDIS-09-18-1545-PDN.

Monaco, L. C. (1977). Consequences of the introduction of coffee rust into Brazil. Annals of the New York Academy of Sciences 287(1):57-71. DOI: http://doi. org/10.1111/j.1749-6632.1977.tb34231.x.

Mori, Y., Sato, Y. and Takamatsu, S. (2000). Molecular phylogeny and radiation time of Erysiphales inferred from the nuclear ribosomal DNA sequences. Mycoscience 41(5):437-447. DOI: https://doi. org/10.1007/BF02461662.

Mulder, J.L. and Holliday, P. (1971). Entyloma oryzae. C.M.I. Descriptions of Pathological Fungi and Bacteria 296:1-2.

Nair, K. (2010). Cocoa (Theobroma cacao L.). In: K. P. P. Nair (Ed.), The Agronomy and Economy of Important Tree Crops of the Developing World, Elsevier Pp. 131180.

Nalley, L., Tsiboe, F., Durand-Morat, A., Shew, A. and Thoma, G. (2016). Economic and environmental impact of rice blast pathogen (Magnaporthe oryzae) alleviation in the United States. PLOS One 11(12):e0167295. DOI: https://doi.org/10.1371/journal.pone.0167295.

Naranjo-Ortiz, M.A. and Gabaldón, T. (2019). Fungal evolution: diversity, taxonomy and phylogeny of the Fungi. Biological Reviews 94(6):2115-2137.

Nascimento, A.D., Lima, M.O., Feijó, F. M., Júnior, J.H., Sobrinho, R.R., Assunção, I.P. and Lima, G.S. (2019). First Report of Colletotrichum aeschynomenes Causing Anthracnose in Cacao (Theobroma cacao) in Brazil. Plant Disease 103(12):3284-3284. DOI: https://doi. org/10.1094/PDIS-11-18-2047-PDN

Newcombe, G. and Chastagner, G.A. (1993). A leaf rust epidemic of hybrid poplar along the lower Columbia River caused by Melampsora medusae. Plant Disease 77:528-531. DOI: https://dx.doi.org/10.1094/PD-770528 .

Nieuwoudt, A., Human, M.P., Craven, M., and Crampton, B.G. (2018). Genetic differentiation in populations of Exserohilum turcicum from maize and sorghum in South Africa. Plant Pathology 67(7):1483-1491. DOI: https://doi.org/10.1111/ppa.12858.

Nilsson, R.H., Hyde, K.D., Pawłowska, J., Ryberg, M., Tedersoo, L., Aas, A. B., ... and Arnold, A. E. (2014). Improving ITS sequence data for identification of plant pathogenic fungi. Fungal Diversity 67(1):11-19. DOI: https://doi.org/10.1007/s13225-014-0291-8

O’Connell, R. J., Thon, M. R., Hacquard, S., Amyotte, S.G., Kleemann, J., Torres, M.F., ... and Altmüller, J. (2012). Lifestyle transitions in plant pathogenic Colletotrichum fungi deciphered by genome and transcriptome analyses. Nature Genetics 44(9):10601065. DOI: https://doi.org/10.1038/ng. 2372.

Owings, L. (2020), Crop disease pandemic coming 'sooner rather than later, SCIDEV.net. Available from: https:// www.scidev.net/global/agriculture/feature/crop- 
disease-pandemic-coming-sooner-rather-than-later. html (Published on 13/07/2020).

Padamsee, M., Kumar, T.A., Riley, R., Binder, M., Boyd, A., Calvo, A.M., ... and LaButti, K. (2012). The genome of the xerotolerant mold Wallemia sebi reveals adaptations to osmotic stress and suggests cryptic sexual reproduction. Fungal Genetics and Biology 49(3):217226. DOI: https://doi.org/10.1016/j.fgb.2012.01.007.

Petrini, O. (1991). Fungal Endophytes of Tree Leaves. In: J. H. Andrews and S. S. Hirano (Eds.), Microbial Ecology of Leaves, Brock/Springer Series in Contemporary Bioscience, Springer, New York Pp. 179-197. DOI: https://doi.org/10.1007/978-1-4612-3168-4_9.

Pirondi, A., Pérez-García, A., Portillo, I., Battistini, G., Turan, C., Brunelli, A. and Collina, M. (2015). Occurrence of chasmothecia and mating type distribution of Podosphaera xanthii, a causal agent of cucurbit powdery mildew in northern Italy. Journal of Plant Pathology 97(2): DOI: http://dx.doi.org/10.4454/ JPP.V97I2.018.

Rabelo, H.D.O., Santos, L.D.S., Diniz, G.M.M., Marin, M.V., Braz, L.T. and McCreight, J.D. (2017). Cucurbits powdery mildew race identity and reaction of melon genotypes 1. Pesquisa Agropecuária Tropical 47(4):440-447. DOI: https://doi.org/10.1590/1983$40632017 \mathrm{v} 4749537$.

Redlin, S. . (1991). Discula destructiva sp. nov., cause of dogwood anthracnose. Mycologia 83(5):633-642. DOI: https://doi.org/10.1080/00275514.1991.12026062

Rincão, M.P., Carvalho, M.C.D.C.G.D., Nascimento, L.C., Lopes-Caitar, V.S., Carvalho, K.D., Darben, L.M., Yokoyama, A., Carazzolle, M.F., Abdelnoor, R. and Marcelino-Guimarães, F.C. (2018). New insights into Phakopsora pachyrhizi infection based on transcriptome analysis in planta. Genetics and Molecular Biology 41(3):671-691. DOI: http://dx.doi.org/10.1590/16784685-gmb-2017-0161.

Rodriguez-Salamanca, L.M., Naegele, R.P., QuesadaOcampo, L.M. and Hausbeck, M.K. (2018). Inoculation Method, Temperature, and Relative Humidity Affect Leaf and Neck Anthracnose, a New Onion Disease in Michigan. Plant Health Progress 19(1):64-68. DOI: https://doi.org/10.1094/PHP-10-17-0063-RS.

Rojas, E.I., Rehner, S.A., Samuels, G.J., Van Bael, S.A., Herre, E.A., Cannon, A., Chen, R., Pang, J., Wang, R., Zhang, Y., Peng, Y. and Sha, T. (2010). Colletotrichum gloeosporioides s.l. associated with Theobroma cacao and other plants in Panama: multilocus phylogenies distinguish host-associated pathogens from asymptomatic endophytes. Mycologia 102(6): 13181338. DOI: https://doi.org/10.3852/09-244.

Rooney-Latham, S., Lutz, M., Blomquist, C.L., Romberg, M.K., Scheck, H.J. and Piątek, M. (2017). Entyloma helianthi: identification and characterization of the causal agent of sunflower white leaf smut. Mycologia 109(3): 520-528. DOI: https://doi.org/10.1080/002755 14.2017.1362314.

Rossman, A.Y. (2008). The impact of invasive fungi on agricultural ecosystems in the United States. Journal Biological Invasions 11(1):97-107. DOI: https://doi. org/10.1007/978-1-4020-9680-8_7.
Rossman, A.Y., Farr, D.F. and Castlebury, L.A. (2007). A review of the phylogeny and biology of the Diaporthales. Mycoscience 48(3):135-144. DOI: https://doi.org/10.1007/S10267-007-0347-7.

Saleh, D., Milazzo, J., Adreit, H., Fournier, E. and Tharreau, D. (2014). South-East Asia is the center of origin, diversity and dispersion of the rice blast fungus, Magnaporthe oryzae. New Phytologist 201(4): 14401456. DOI: https://doi.org/10.1111/nph.12627.

Salgado-Salazar, C., Shiskoff, N., LeBlanc, N., Ismaiel, A.A., Collins, M., Cubeta, M.A. and Crouch, J.A. (2019). Coccinonectria pachysandricola, causal agent of a new foliar blight disease of Sarcococca hookeriana. Plant Disease 103(6): 1337-1346. DOI: https://doi. org/10.1094/PDIS-09-18-1676-RE.

Sangpueak, R., Phansak, P. and Buensanteai, N. (2018). Morphological and molecular identification of Colletotrichum species associated with cassava anthracnose in Thailand. Journal of Phytopathology 166(2): 129-142. DOI: https://doi.org/10.1111/ jph.12669.

Santana, M.F., Zambolim, E.M., Caixeta, E.T. and Zambolim, L. (2018). Population genetic structure of the coffee pathogen Hemileia vastatrix in Minas Gerais, Brazil. Tropical Plant Pathology 43(5): 473-476. DOI: https://doi.org/10.1007/s40858-018-0246-9.

Savary, S., Willocquet, L., Elazegui, F.A., Castilla, N.P. and Teng, P.S. (2000). Rice pest constraints in tropical Asia: quantification of yield losses due to rice pests in a range of production situations. Plant Disease 84(3): 357-369. DOI: http://dx.doi.org/10.1094/PDIS.2000.84.3.357

Savchenko, K.G., Carris, L.M., Demers, J., Manamgoda, D.S. and Castlebury, L.A. (2017). What causes flag smut of wheat?. Plant Pathology 66(7): 1139-1148. DOI: https://doi.org/10.1111/ppa.12657.

Savchenko, K.G., Harper, S.R., Carris, L.M. and Castlebury, L.A. (2020). Urocystis cumminsii sp. nov., a smut fungus on Themidaceae from Arizona. Mycotaxon 134(4):591-599. DOI: https://doi.org/10.5248/134.591

Savchenko, K.G., Heluta, V.P., Wasser, S.P. and Nevo, E. (2014). Rust fungi (Pucciniales) of Israel. I. All genera except Puccinia and Uromyces with Caeoma origani sp. nov. Nova Hedwigia 98(1-2):163-178. DOI: https:// doi.org/10.1127/0029-5035/2013/0122.

Savile, D.B.O. (1971). Coevolution of the Rust Fungi and Their Hosts. The Quarterly Review of Biology 46(3):211-218.

Schafer, J.F. (1987). Rusts, smuts, and powdery mildew. In: E.G. Heyne (Ed.), Wheat and wheat improvement, American Society of Agronomy, Crop Science Society of America and Soil Science Society of America, Wisconsin Pp. 542-584.

Scheffer, R. P. (1997). The nature of disease in plants. Cambridge University Press, Cambridge, 336.

Shenoy, B.D., Jeewon, R. and Hyde, K.D. (2007). Impact of DNA sequence-data on the taxonomy of anamorphic fungi. Fungal Diversity. 26:1-54.

Shivas, R.G., Tan, Y.P., Edwards, J., Dinh, Q., Maxwell, A., Andjic, V., ... and Coates, L.M. (2016). Colletotrichum species in Australia. Australasian Plant Pathology 45(5): 447-464. DOI: https://doi.org/10.1007/s13313- 
016-0443-2.

Shrestha, S.K., Cochran, A., Mengistu, A., Lamour, K., Castro-Rocha, A. and Young-Kelly, H. (2017). Genetic diversity, QoI fungicide resistance, and mating type distribution of Cercospora sojina-Implications for the disease dynamics of frogeye leaf spot on soybean. PLOS One 12(5): e0177220. DOI: https://doi.org/10.1371/ journal.pone.0177220.

Singh, R.P., Hodson, D.P., Huerta-Espino, J., Jin, Y., Njau, P., Wanyera, R., Herrera-Foessel, S. A. and Ward, R.W. (2008). Will stem rust destroy the world's wheat crop? Advances in Agronomy 98:271-309. DOI: http://doi. org/10.1016/s0065-2113(08)00205-8.

Sinniah, G.D., Kumara, K.W., Karunajeewa, D.G.N.P. and Ranatunga, M.A.B. (2016). Development of an assessment key and techniques for field screening of tea (Camellia sinensis L.) cultivars for resistance to blister blight. Crop Protection 79:143-149. DOI: https://doi. org/10.1016/j.cropro.2015.10.017.

Sivanesan, A. (1991). The taxonomy and biology of dematiaceous hyphomycetes and their mycotoxins. In: B. R. Champ, E. Highley, A. D. Hocking and J. I. Pitt (Eds.), Fungi and Mycotoxins in Stored Products, Australian Centre for International Agricultural Research, Canberra Pp. 47-64.

Sivanesan, A. and Gibson, I.A.S. (1976). Diplocarpon earliana. C.M.I. Descriptions of Pathogenic Fungi and Bacteria 486: 1-2.

Slippers, B. and Wingfield, M.J. (2007). Botryosphaeriaceae as endophytes and latent pathogens of woody plants: diversity, ecology and impact. Fungal Biology Reviews 21(2-3):90-106. DOI: https://doi.org/10.1016/j. fbr.2007.06.002.

Smith, I.M., Dunez, J., Phillips, D. H., Lelliott, R.A. and Archer, S.A. (1988). European handbook of plant diseases. Blackwell Scientific Publications, Oxford, 598.

Smith, J.A., Blanchette, R.A. and Newcombe, G. (2004). Molecular and morphological characterization of the willow rust fungus, Melampsora epitea, from arctic and temperate hosts in North America. Mycologia 96:13301338. DOI: https://doi.org/10.2307/3762149

Sobanbabu, G., Sabarinathan, K.G., Parthiban, V.K. and Ramamoorthy, V. (2018). Isolation, Screening and Identification of Virulent Isolates of Bipolaris oryzae Causing Rice Brown Spot and Sarocladium oryzae Causing Sheath Rot Disease. International Journal of Current Microbiology and Applied Sciences 7(9):930-939. DOI: https://doi.org/10.20546/ ijcmas.2018.709.112.

Takamatsu, S. (2004). Phylogeny and evolution of the powdery mildew fungi (Erysiphales, Ascomycota) inferred from nuclear ribosomal DNA sequences. Mycoscience 45(2):147-157. DOI: https://doi. org/10.1007/s10267-003-0159-3.

Takamatsu, S. (2013). Origin and evolution of the powdery mildews (Ascomycota, Erysiphales). Mycoscience 54(1):75-86. DOI: https://doi.org/10.1016/j. myc.2012.08.004.

Takamatsu, S., Ito, H., Shiroya, Y., Kiss, L. and Heluta, V. (2015). First comprehensive phylogenetic analysis of the genus Erysiphe (Erysiphales, Erysiphaceae) I. The Microsphaera lineage. Mycologia 107(3):475-489. DOI: https://doi.org/10.3852/15-007.

Takamatsu, S., Matsuda, S. and Grigaliunaite, B. (2013). Comprehensive phylogenetic analysis of the genus Golovinomyces (Ascomycota: Erysiphales) reveals close evolutionary relationships with its host plants. Mycologia 105(5):1135-1152. DOI: https://doi. org/10.3852/13-046.

Talhinhas, P., Batista, D., Diniz, I., Vieira, A., Silva, D.N., Loureiro, A., Tavares, S., Pereira, A. P., Azinheira, H., Guerra-Guimaraes, L., Várzea, V. and do Céu Silva, M. (2017). The coffee leaf rust pathogen Hemileia vastatrix: one and a half centuries around the tropics. Molecular Plant Pathology 18(8):1039-1051. DOI: https://doi.org/10.1111/mpp.12512.

Tan, Y.P., Madrid, H., Crous, P.W. and Shivas, R.G. (2014). Johnalcornia gen. et. comb. nov., and nine new combinations in Curvularia based on molecular phylogenetic analysis. Australasian Plant Pathology 43(6):589-603. DOI: https://doi.org/10.1007/s13313014-0315-6.

Tan, Y.P., Crous, P.W. and Shivas, R.G. (2016). Eight novel Bipolaris species identified from John L. Alcorn's collections at the Queensland Plant Pathology Herbarium (BRIP). Mycological Progress 15(1011):1203-1214. DOI: https://doi.org/10.1007/s11557016-1240-6.

Tan, Y.P., Crous, P.W. and Shivas, R.G. (2018). Cryptic species of Curvularia in the culture collection of the Queensland Plant Pathology Herbarium. MycoKeys 35(11):1-25. DOI: https://doi.org/10.3897/ mycokeys.35.25665

Terefe, T., Visser, B., Herselman, L., Selinga, T. and Pretorius, Z.A. (2014). First report of Puccinia triticina (leaf rust) race FBPT on wheat in South Africa. Plant Disease 98(7):1001. DOI: https://doi.org/10.1094/ PDIS-12-13-1195-PDN.

Toh, S.S. and Perlin, M.H. (2016). Resurgence of lessstudied smut fungi as models of phytopathogenesis in the omics age. Phytopathology 106(11):1244-1254. DOI: https://doi.org/10.1094/PHYTO-02-16-0075RVW.

Trigiano, R.N., Hadziabdic, D., Mantooth, K., Windham, M.T., Ownley, B.H., Staton, M.E., Miller, S. and Zhang, N. (2016, August). Dogwood anthracnose: the story continues. In: S.C. Hokanson (Ed.), ISHS Acta Horticulturae 1191,III International Symposium on Woody Ornamentals of the Temperate Zone, International Society for Horticultural Science, Minneapolis, Minnesota Pp. 77-82.

Tsai, I., Maharachchikumbura, S.S., Hyde, K.D. and Ariyawansa, H.A. (2018). Molecular phylogeny, morphology and pathogenicity of Pseudopestalotiopsis species on Ixora in Taiwan. Mycological Progress 17(8):941-952. DOI: https://doi.org/10.1007/s11557018-1404-7.

Udayanga, D., Liu, X., McKenzie, E.H., Chukeatirote, E., Bahkali, A.H. and Hyde, K.D. (2011). The genus Phomopsis: biology, applications, species concepts and names of common phytopathogens. Fungal Diversity 
50(1):189-225.

Udayanga, D., Castlebury, L.A., Rossman, A.Y., Chukeatirote, E. and Hyde, K.D. (2014). Insights into the genus Diaporthe: phylogenetic species delimitation in the D. eres species complex. Fungal Diversity 67(1):203-229. DOI: https://doi.org/10.1007/s13225014-0297-2.

Udayanga, D., Castlebury, L.A., Rossman, A.Y., Chukeatirote, E. and Hyde, K.D. (2015). The Diaporthe sojae species complex: Phylogenetic re-assessment of pathogens associated with soybean, cucurbits and other field crops. Fungal Biology 119(5):383-407. DOI: https://doi.org/10.1016/j.funbio.2014.10.009.

Udayanga, D., Liu, X., Crous, P.W., McKenzie, E.H., Chukeatirote, E. and Hyde, K.D. (2012). A multi-locus phylogenetic evaluation of Diaporthe (Phomopsis). Fungal Diversity 56(1):157-171. DOI: https://doi. org/10.1007/s13225-012-0190-9.

Udayanga, D., Manamgoda, D.S., Liu, X., Chukeatirote, E., Hyde, K.D. (2013). What are the common anthracnose pathogens of tropical fruits? Fungal Diversity 61(1):115. DOI: https://doi.org/10.1007/s13225-013-0257-2

Vánky, K. (2004). The smut fungi (Ustilaginomycetes) of Muhlenbergia (Poaceae). Fungal Diversity 16:199-226.

Vanky, K. (2012). Smut Fungi of the World. APS Press, St. Paul, Minnesota, 1458.

Vanky, K., Vanky, C. and Denchev, C.M. (2011). Smut fungi in Africa- a checklist. Mycologia Balcanica 8:177. DOI: http://doi.org/10.5281/zenodo.2550336.

Velásquez, A. C., Castroverde, C. D. M. and He, S. Y. (2018). Plant-pathogen warfare under changing climate conditions. Current Biology 28(10):R619-R634. DOI: https://doi.org/10.1016/j.cub.2018.03.054.

Villarreyna, R., Barrios, M., Vílchez, S., Cerda, R., Vignola, R. and Avelino, J. (2020). Economic constraints as drivers of coffee rust epidemics in Nicaragua. Crop Protection 127: 104980. DOI: https://doi.org/10.1016/j. cropro.2019.104980.

Vinatzer, B.A., Heath, L.S., Almohri, H.M., Stulberg, M.J., Lowe, C. and Li, S. (2019). Cyberbiosecurity Challenges of Pathogen Genome Databases. Frontiers in Bioengineering and Biotechnology 7:106. DOI: https://doi.org/10.3389/fbioe.2019.00106.

Wang, H.N. and Wei, S.H. (2016). First report of Bipolaris leaf blight on Arundo donax caused by Bipolaris sorokiniana in China. Plant Disease 100(11):2322. DOI: https://doi.org/10.1094/PDIS-03-16-0282-PDN.

Weerasooriya, C.R., Kottawaarachchi, J.D., Ranathunga, M.A.B. and Amarakoon, A.M.T. (2018). Correlation between selected morphological and biochemical parameters in a hybrid tea population with the blister blight disease. Research Symposium on Pure and Applied Sciences 2018, Faculty of Science, University of Kelaniya, Sri Lanka, p18.

Whiston, E., and Taylor, J.W. (2016). Comparative phylogenomics of pathogenic and nonpathogenic species. G3: Genes, Genomes, Genetics 6(2):235-244. DOI: https://doi.org/10.1534/g3.115.022806

Wikee, S., Udayanga, D., Crous, P.W., Chukeatirote, E., McKenzie, E.H., Bahkali, A.H., Dai, D.and Hyde, K.D. (2011). Phyllosticta - an overview of current status of species recognition. Fungal Diversity 51(1):43-61. DOI: https://doi.org/10.1007/s13225-011-0146-5.

World Coffee Research. (2018) Available from: https:// worldcoffeeresearch.org/work/yield-quality-andcoffee-leaf-rust/

Wu, G., Schuelke, T.A., Iriarte, G. and Broders, K. (2020). The genome of the butternut canker pathogen, Ophiognomonia clavigignenti-juglandacearum shows an elevated number of genes associated with secondary metabolism and protection from host resistance responses. PeerJ 8: e9265. DOI: https://doi. org/10.7717/peerj.9265.

Xue, M., Yang, J., Li, Z., Hu, S., Yao, N., Dean, R.A., Zhao, W., Shen, M., Zhang, H., Li, C. and Liu, L. (2012). Comparative analysis of the genomes of two field isolates of the rice blast fungus Magnaporthe oryzae. PLOS Genetics 8(8): e1002869. DOI: https://doi. org/10.1371/journal.pgen.1002869.

Yamaoka, Y. (2014). Recent outbreaks of rust diseases and the importance of basic biological research for controlling rusts. Journal of General Plant Pathology 80(5):375388. DOI: https://doi.org/10.1007/s10327014-0529-z.

Yorinori, J.T., Paiva, W.M., Frederick, R.D., Costamilan, L.M., Bertagnolli, P.F., Hartman, G. E., Godoy, C.V. and Nunes Jr, J. (2005). Epidemics of soybean rust (Phakopsora pachyrhizi) in Brazil and Paraguay from 2001 to 2003. Plant Disease 89(6):675-677. DOI: https://doi.org/10.1094/PD-89-0675.

Zhang, G. and Bradley, C.A. (2014). Survival of Cercospora sojina on soybean leaf debris in Illinois. Plant Health Progress 15(3):92-96. DOI: https://doi.org/10.1094/ PHP-RS-14-0005

Zhang, N. and Blackwell, M. (2001). Molecular phylogeny of dogwood anthracnose fungus (Discula destructiva) and the Diaporthales. Mycologia 93(2):355-365. DOI: https://doi.org/10.1080/00275514.2001.12063167.

Zhang, N., Castlebury, L.A., Miller, A. N., Huhndorf, S. M., Schoch, C.L., Seifert, K.A., Rossman, A.Y., Rogers, J.D., Kohlmeyer, J., Volkmann-Kohlmeyer, B. and Sung, G.H. (2006). An overview of the systematics of the Sordariomycetes based on a four-gene phylogeny. Mycologia 98(6):1076-1087. DOI: https://doi.org/10.1 080/15572536.2006.1183263. 